\title{
Human brain mechanisms of pain perception and regulation in health and disease
}

\author{
A. Vania Apkarian ${ }^{\mathrm{a}, *}$, M. Catherine Bushnell ${ }^{\mathrm{b}}$, Rolf-Detlef Treede ${ }^{\mathrm{c}}$, Jon-Kar Zubieta ${ }^{\mathrm{d}}$ \\ ${ }^{a}$ Department of Physiology, Northwestern University Medical School, 303 E. Chicago Avenue, Ward 5-003, Chicago, IL 60611, USA \\ ${ }^{\mathrm{b}}$ Department of Anesthesia, McGill University, Montreal, Canada \\ ${ }^{\mathrm{c}}$ Institute of Physiology and Pathophysiology, Johannes Gutenberg University, Mainz, Germany \\ ${ }^{\mathrm{d}}$ Department of Psychiatry and Radiology, University of Michigan, Ann Arbor, MI, USA
}

Received 31 August 2004; accepted 2 November 2004

Available online 21 January 2005

\begin{abstract}
Context: The perception of pain due to an acute injury or in clinical pain states undergoes substantial processing at supraspinal levels. Supraspinal, brain mechanisms are increasingly recognized as playing a major role in the representation and modulation of pain experience. These neural mechanisms may then contribute to interindividual variations and disabilities associated with chronic pain conditions.

Objective: To systematically review the literature regarding how activity in diverse brain regions creates and modulates the experience of acute and chronic pain states, emphasizing the contribution of various imaging techniques to emerging concepts.

Data Sources: MEDLINE and PRE-MEDLINE searches were performed to identify all English-language articles that examine human brain activity during pain, using hemodynamic (PET, fMRI), neuroelectrical (EEG, MEG) and neurochemical methods (MRS, receptor binding and neurotransmitter modulation), from January 1, 1988 to March 1, 2003. Additional studies were identified through bibliographies.

Study Selection: Studies were selected based on consensus across all four authors. The criteria included well-designed experimental procedures, as well as landmark studies that have significantly advanced the field.

Data Synthesis: Sixty-eight hemodynamic studies of experimental pain in normal subjects, 30 in clinical pain conditions, and 30 using neuroelectrical methods met selection criteria and were used in a meta-analysis. Another 24 articles were identified where brain neurochemistry of pain was examined. Technical issues that may explain differences between studies across laboratories are expounded. The evidence for and the respective incidences of brain areas constituting the brain network for acute pain are presented. The main components of this network are: primary and secondary somatosensory, insular, anterior cingulate, and prefrontal cortices (S1, S2, IC, ACC, PFC) and thalamus (Th). Evidence for somatotopic organization, based on 10 studies, and psychological modulation, based on 20 studies, is discussed, as well as the temporal sequence of the afferent volley to the cortex, based on neuroelectrical studies. A meta-analysis highlights important methodological differences in identifying the brain network underlying acute pain perception. It also shows that the brain network for acute pain perception in normal subjects is at least partially distinct from that seen in chronic clinical pain conditions and that chronic pain engages brain regions critical for cognitive/emotional assessments, implying that this component of pain may be a distinctive feature between chronic and acute pain. The neurochemical studies highlight the role of opiate and catecholamine transmitters and receptors in pain states, and in the modulation of pain with environmental and genetic influences.

Conclusions: The nociceptive system is now recognized as a sensory system in its own right, from primary afferents to multiple brain areas. Pain experience is strongly modulated by interactions of ascending and descending pathways. Understanding these
\end{abstract}

\footnotetext{
${ }^{*}$ Corresponding author. Tel.: +1 312503 0404; fax: +1 312503 5101.

E-mail address: a-apkarian@northwestern.edu (A.V. Apkarian).
}

1090-3801/\$30 (c) 2004 Published by Elsevier Ltd on behalf of European Federation of Chapters of the International Association for the Study of Pain.

doi:10.1016/j.ejpain.2004.11.001 
modulatory mechanisms in health and in disease is critical for developing fully effective therapies for the treatment of clinical pain conditions.

(C) 2004 Published by Elsevier Ltd on behalf of European Federation of Chapters of the International Association for the Study of Pain.

\section{Introduction}

Up to 15 years ago and until the advent of non-invasive human brain imaging methodologies, our understanding of the role of the brain, above the spinal cord, in pain processing was limited and based primarily on animal anatomical and electrophysiological studies. The specific role of the cerebral cortex remained unsettled and heavily influenced by pronouncements of Head and of Penfield that questioned the participation of the cortex in human pain states. There has been a veritable revolution in these concepts, driven mainly by new technologies that have made the human brain available for direct examination and comparison between normal subjects and clinical pain patients. We can now assert the role of the cortex in pain perception and begin to subdivide different cortical and sub-cortical areas as to their specific role in pain perception and modulation. In this systematic review we highlight these advances in the field. We perform a meta-analysis comparing brain regions observed to be active with different brain imaging modalities. Brain imaging technologies available for studying the brain in pain are summarized in Table 1, where spatial and temporal properties of the different methods are indicated as well as their primary impact in pain research. We also perform a meta-analysis for experimental pain in normal subjects as compared to chronic clinical pain conditions. These analyses highlight the advantages of different imaging techniques in identifying distinct properties of the brain network for pain, and show that the brain activity in this network undergoes several changes in chronic clinical pain conditions. Moreover, we review the human brain imaging evidence for somatotopy, psychological modulation, temporal sequence of cortical activity, and the role of opiates and catecholamines in the modulation of pain.

\section{Methods}

Papers related to the topic were identified by searching for each technology included in this review, combined with the word pain. Ovid PRE-MEDLINE and MEDLINE databases were searched between January 1, 1988 and March 1, 2003. The search terms were: single photon and SPECT; electroencephalography and EEG; and magnetoencephalography and MEG; laser evoked; magnetic resonance spectroscopy and MRS; positron emission and PET; and functional MRI and
fMRI. These terms were combined with the word pain, limiting the outputs to English language and human studies. The terms electroencephalography, magnetoencephalography, MEG and EEG yielded 80,196 articles. Combining these terms with pain for the years 19882003, limited to English and Human studies $(104,124$ articles), resulted in 480 articles. Similarly, the combinations: positron emission, PET and pain identified 274 articles; functional MRI, fMRI and pain identified 88 articles; single photon emission, SPECT, and pain identified 288 articles; magnetic resonance spectroscopy and MRS were combined with the term brain and then with pain resulting in 11 articles. Additional papers were identified from bibliographies. From this set of articles, papers not directly related to pain, case reports, reviews, and studies of acupuncture were eliminated. Of the remaining studies only those that satisfied quality criteria of indicating group responses, having well-defined painful stimuli, or pain conditions, and proper control states or groups were included in the review. We refrained from using more rigid criteria mainly because of the diversity of the studies. eTables 1-5 list the papers that examine pain related brain activity in normal subjects, using PET, fMRI, and SPECT, for brain areas reported active in pain (eTable 1), for somatotopic organization of pain representation in the brain (eTable 2), psychological modulation of pain (eTable 3 ), brain areas reported activated for pain when monitored for electrical or magnetic signals, EEG and MEG (eTable 4), and for clinical pain related brain activity in patients, using PET, fMRI, SPECT, perfusion-MRI and MRS, including studies using deep brain stimulation and capsaicin induced allodynia in normal subjects (eTable 5). The review also covers studies of neuroreceptor and neurotransmitter modulation by pain ( 24 articles), these are only covered in the narrative section.

Meta-analysis was done to calculate an incidence measure for six brain regions, to contrast between imaging modalities (Table 2) and, between brain regions active for pain in normal subjects in comparison to pain in clinical conditions (Table 3); data derived from eTables 1, 4, and 5. Incidence for each brain region was calculated based on the inclusion of an area in the given study or given contrast and the area showing statistically significant involvement in the condition or contrast. eTable 1 lists 32 PET and 36 fMRI studies; all used in the incidence measures. One study (Iadarola et al., 1998) is listed in eTables 1 and 5; in the former the results for capsaicin pain is included while in the 
Table 1

Brain mapping techniques, their properties, and application in pain studies

\begin{tabular}{|c|c|c|c|c|c|c|}
\hline Method & Energy source & $\begin{array}{l}\text { Spatial } \\
\text { resolution }(\mathrm{mm})\end{array}$ & $\begin{array}{l}\text { Temporal } \\
\text { resolution (s) }\end{array}$ & Constraints & Output measured & $\begin{array}{l}\text { Application in pain } \\
\text { studies }\end{array}$ \\
\hline FMRI & Radio waves & $4-5$ & $4-10$ & $\begin{array}{l}\text { Immobilization, loud, } \\
\text { cooperation }\end{array}$ & $\begin{array}{l}\text { Relative cerebral blood } \\
\text { flow }\end{array}$ & $\begin{array}{l}\text { Most used, mainly for } \\
\text { localizing brain activity }\end{array}$ \\
\hline EEG/MEG & Intrinsic electricity & 10 & 0.001 & $\begin{array}{l}\text { Artifact, lack of unique } \\
\text { localization }\end{array}$ & $\begin{array}{l}\text { Electrophysiology of } \\
\text { brain events }\end{array}$ & $\begin{array}{l}\text { Increasing in use, mainly } \\
\text { for detecting temporal } \\
\text { sequences }\end{array}$ \\
\hline Nuclear (PET/SPECT) & Radiation & $5-10$ & $60-1000$ & $\begin{array}{l}\text { Radiation limits, } \\
\text { immobilization }\end{array}$ & $\begin{array}{l}\text { Physiology, } \\
\text { neurochemistry, absolute } \\
\text { values }\end{array}$ & $\begin{array}{l}\text { Decreasing in use, } \\
\text { becoming limited to } \\
\text { neurochemistry }\end{array}$ \\
\hline MR spectroscopy & Radio waves & 10 & $10-100$ & Immobilization, loud & $\begin{array}{l}\text { Relative chemical } \\
\text { concentrations }\end{array}$ & $\begin{array}{l}\text { Recently used, for } \\
\text { detecting long term } \\
\text { changes in brain } \\
\text { chemistry }\end{array}$ \\
\hline \multicolumn{7}{|c|}{ Brain imaging techniques available but rarely or not yet used in pain studies or, not covered in this review } \\
\hline Structural MRI & Radio waves & 1 & N/A & Immobilization, loud & $\begin{array}{l}\text { Structure, vasculature, } \\
\text { white matter }\end{array}$ & \\
\hline Post mortem & N/A & 0.001 & N/A & Post mortem & $\begin{array}{l}\text { Microarchitecture, } \\
\text { chemoarchirtecture }\end{array}$ & \\
\hline $\begin{array}{l}\text { Trans-cranial magnetic/ } \\
\text { electric stimulation }\end{array}$ & Magnetic/electric fields & 10 & 0.01 & $\begin{array}{l}\text { Risk of seizures, } \\
\text { immobilization, loud }\end{array}$ & $\begin{array}{l}\text { Electrophysiology, } \\
\text { conduction times }\end{array}$ & \\
\hline $\begin{array}{l}\text { Near-infrared } \\
\text { spectroscopy and } \\
\text { imaging }\end{array}$ & Near-infrared & 0.05 & 0.05 & $\begin{array}{l}\text { Immobilization, } \\
\text { surface }>\text { depth, } \\
\text { limited field of view }\end{array}$ & $\begin{array}{l}\text { Relative cerebral blood } \\
\text { flow }\end{array}$ & \\
\hline $\begin{array}{l}\text { Single or multi-unit } \\
\text { electrophysiology }\end{array}$ & Intrinsic electricity & $0.01-1$ & 0.01 & $\begin{array}{l}\text { Invasive, direct access to } \\
\text { brain }\end{array}$ & $\begin{array}{l}\text { Electrophysiology, not } \\
\text { covered in this review }\end{array}$ & \\
\hline
\end{tabular}

N/A, not applicable. For more details on these techniques, see Anon. (2002); also see Davis (2003) for the application of fMRI to pain studies, and Peyron et al. (2000) for properties of PET and

fMRI in pain studies; Kakigi et al. (2003) for differential application of EEG and MEG to pain research; Wiech et al. (2000) for the application of EEG and MEG to studies of chronic pain;

Pridmore and Oberoi (2000) for application of TMS to pain studies; Hoshi (2003) regarding technical details of near-infrared spectroscopy (NIRS). 
latter only results for allodynia are listed. eTable 3 lists 10 EEG studies and 20 MEG studies; all are used in the incidence comparisons in Table 2. eTable 5 lists the studies indicating brain areas involved in clinical pain conditions. Of those, only 30 PET and fMRI studies were used in the incidence calculations, perfusion-MRI, MRS, deep brain stimulation, and studies of allodynia in normal subjects were excluded from incidence measures. Thus, the eTables provide all the data used for incidence calculations.

\section{Results}

\subsection{Acute pain}

\subsubsection{Defining a pain network: hemodynamic studies}

Hemodynamic correlates of pain were first imaged in the human brain in the 1970s by Lassen and colleagues (Lassen et al., 1978) using the radioisotope ${ }^{133} \mathrm{Xe}$. This technique provided little spatial resolution, but suggested that there was an increased blood flow to the frontal lobes during pain. The first three human brain imaging studies of pain using modern technologies were published in the early 1990s by Talbot et al. (1991) and Jones et al. (1991), using PET, and Apkarian et al. (1992), using SPECT. All three studies used heat pain, and although there were differences in the results of these studies, together they indicated that multiple cortical and sub-cortical regions are activated during shortduration painful cutaneous heat stimuli presented to normal subjects. Since these first experiments, many other PET and fMRI studies have been conducted examining the neural processing of painful cutaneous heat in humans and confirm that multiple brain regions are activated (eTable 1). Both primary somatosensory cortex (S1) and secondary somatosensory cortex (S2) are commonly activated in heat pain studies. Evidence suggests that the nociceptive input into these regions at least partially underlies the perception of sensory features of pain (Coghill et al., 1999; Peyron et al., 1999; Bushnell et al., 1999; Chen et al., 2002). Anterior cingulate (ACC) and insular (IC) cortices, both components of the limbic system, are activated during the majority of PET or fMRI studies of heat pain, and these regions have been implicated in the affective processing of pain (Rainville et al., 1997; Tolle et al., 1999; Fulbright et al., 2001). Prefrontal cortical areas, as well as parietal association areas, are also sometimes activated by heat pain and may be related to cognitive variables, such as memory or stimulus evaluation (Coghill et al., 1999; Strigo et al., 2003). Motor and pre-motor cortical areas are on occasion activated by heat pain, but these activations are less reliable, suggesting they may be related to pain epiphenomena, such as suppression of movement or actual pain-evoked movements themselves. Motor cortex activation may be interpreted or obscured as S1 activity, and some midcinglate areas activated by painful stimuli can be confounded by supplementary motor activity. Subcortical activations are also observed, most notably in thalamus (Th), basal ganglia, and cerebellum (eTable 1). Fig. 1 illustrates the brain regions most commonly reported activated in pain studies. The indicated locations approximate the brain regions discussed in this review and should be used only as a general guide because within and across imaging studies there are important differences in specific activation sites. For example, we illustrate prefrontal activity mainly within the medial prefrontal cortex, although recent studies indicate important interactions between medial and lateral prefrontal areas. Other brain areas that we think are importantly involved in pain perception are also included in the figure even though their roles are not covered in this review.

In examining eTable 1, it becomes evident that there are many differences, as well as similarities, in brain regions that are reported to be activated. Some of these differences can be explained by variations in technical procedures and differences in statistical analyses and power: some analyses use simple subtractions others use regression comparisons; methods and assumptions for calculating variance differ among laboratories and analysis techniques; methods of accounting for multiple comparisons varies; number of subjects used and hence the power of a statistical test varies greatly among experiments. It must be remembered that, as with any statistical test, a negative result does not mean that there is no neuronal activity in the specific region; it only means that no activation was detected using a stringent statistical requirement that biases results towards many more false negative than false positive findings. Many differences most probably reflect the fact that different individuals have dissimilar experiences when presented with a painful stimulus. Both gender and genetic factors are important determinants of pain, and imaging studies confirm these differences (Paulson et al., 1998; Zubieta et al., 1999). Further, for any individual, the pain experience will vary in different experiments, depending upon the environment, experimenter, instructions, stimulus and procedural design. However, not surprisingly, even within a single experiment, in which all of the factors are standardized, there are large individual differences in the subjective pain experience, which is reflected in distinctive patterns of brain activity (Davis et al., 1998).

Despite of these important differences across studies, our meta-analysis indicates that incidence for the six most commonly reported areas (ACC, S1, S2, IC, Th, PFC, Table 2) are similar between hemodynamic imaging modalities PET and fMRI. The borderline difference in incidence for PFC activation between PET and fMRI seems to be due to reduced PFC activation reports in older PET studies, most likely due to the lower sensitiv- 
eTable 1

Brain areas activated for pain in normal subjects

\begin{tabular}{|c|c|c|c|}
\hline Source & Scan type & Pain stimulus & Areas activated \\
\hline Jones et al. (1991) & PET & Contact heat & $\mathrm{ACC}, \mathrm{Th}, \mathrm{BG}$ \\
\hline Talbot et al. (1991) & PET & Contact heat & $\mathrm{S} 1, \mathrm{~S} 2, \mathrm{ACC}$ \\
\hline Apkarian et al. (1992) & SPECT & Contact heat & S1 decrease \\
\hline Crawford et al. (1993) & SPECT & Ischemia & S1 \\
\hline Casey et al. (1994) & PET & Contact heat & S1, S2, IC, ACC, Th, BS, CB \\
\hline Davis et al. (1995) & fMRI & Electric shock & $\mathrm{S} 1, \mathrm{ACC}$ \\
\hline Casey et al. (1996) & PET & Contact heat & S2, IC, ACC, Th, PFC, PMC, PCC, BG, BS, CB \\
\hline Craig et al. (1996) & PET & Contact heat & S1, S2, IC, ACC \\
\hline Craig et al. (1996) & PET & Cold & $\mathrm{S} 1, \mathrm{~S} 2, \mathrm{IC}, \mathrm{ACC}$ \\
\hline Craig et al. (1996) & PET & Thermal grill illusion & S1, S2, IC, ACC \\
\hline Vogt et al. (1996) & PET & Contact heat & $\mathrm{ACC}$ \\
\hline Aziz et al. (1997) & PET & Painful esophagus distention & S1, S2, IC, ACC \\
\hline Davis et al. (1997) & fMRI & Electric shock & $\mathrm{ACC}$ \\
\hline Derbyshire et al. (1997) & PET & Contact heat & S1, ACC, Th, PFC, PMC, PP, Hippo, Amyg decrease \\
\hline Rainville et al. (1997) & PET & Contact heat & S1, S2, IC, ACC, \\
\hline Silverman et al. (1997) & PET & Rectal distension & $\mathrm{ACC}$ \\
\hline Svensson et al. (1997) & PET & Laser heat & S2, IC, Th, PFC, PP, PMC, CB \\
\hline Svensson et al. (1997) & PET & Muscular electric shock & S1, S2, IC, ACC, Th, PP, CB, BG \\
\hline Binkofski et al. (1998) & fMRI & Esophagus distension & S1, S2, IC, ACC, PMC \\
\hline Coghill et al. (1998) & PET & Capsaicin & Global decrease \\
\hline Davis et al. (1998) & fMRI & Cold & $\mathrm{S} 2, \mathrm{IC}, \mathrm{Th}$ \\
\hline Davis et al. (1998) & fMRI & Contact heat & $\mathrm{S} 2, \mathrm{IC}, \mathrm{Th}$ \\
\hline Disbrow et al. (1998) & fMRI & Electric shock & $\mathrm{S} 1, \mathrm{~S} 2, \mathrm{CB}$ \\
\hline Iadarola et al. (1998) & PET & Capsaicin & S1, IC, ACC, Th, CB, BG, SMA, PAG, superior colliculus \\
\hline Jones et al. (1998) & fMRI & Cold & ACC, PFC, parieto-occipital \\
\hline Derbyshire and Jones (1998) & PET & Contact heat tonic & IC, ACC, Th, PFC, BG \\
\hline Derbyshire et al. (1998) & PET & Contact heat & $\mathrm{ACC}$ \\
\hline Oshiro et al. (1998) & fMRI & Electric shock & $\mathrm{S} 2, \mathrm{IC}$ \\
\hline Paulson et al. (1998) & PET & Contact heat & $\mathrm{IC}, \mathrm{ACC}, \mathrm{PMC}, \mathrm{PFC}, \mathrm{CB}$ \\
\hline Porro et al. (1998) & fMRI & Ascorbic acid & S1, ACC, PMC, M1 \\
\hline Svensson et al. (1998) & PET & Contact heat & $\mathrm{S} 1, \mathrm{~S} 2, \mathrm{IC}, \mathrm{ACC}$ \\
\hline Apkarian et al. (1999) & fMRI & Contact heat & $\mathrm{IC}, \mathrm{PP}$ \\
\hline Baciu et al. (1999) & fMRI & Rectal distension & S1, S2, IC, ACC, PFC, PCC, PP, occipital \\
\hline Becerra et al. (1999) & fMRI & Contact heat & S1, S2, IC, PFC, CB Amyg, Hypo decrease \\
\hline Gelnar et al. (1999) & fMRI & Contact heat & S1, S2, IC, PCC, M1 \\
\hline Coghill et al. (1999) & PET & Contact heat & S1, S2, IC, ACC, Th, PFC, BG, CB \\
\hline Peyron et al. (1999) & PET & Contact heat & $\mathrm{S} 1, \mathrm{~S} 2, \mathrm{IC}, \mathrm{ACC}, \mathrm{Th}, \mathrm{PFC}$ \\
\hline Tolle et al. (1999) & PET & Contact heat & Th, ACC, PFC, PCC, PVG \\
\hline Apkarian et al. (2000) & fMRI & Contact heat & $\mathrm{S} 1, \mathrm{~S} 2, \mathrm{IC}, \mathrm{M} 1$ \\
\hline Creac'h et al. (2000) & fMRI & Cutaneous pressure & S1, S2, IC, ACC, Th, PFC, PCC, temporal \\
\hline Kwan et al. (2000) & fMRI & Contact heat & $\mathrm{ACC}$ \\
\hline Kwan et al. (2000) & fMRI & Cold & ACC \\
\hline Mertz et al. (2000) & fMRI & Rectal distension (normal subjects) & IC, ACC, Th, PFC \\
\hline Tracey et al. (2000) & fMRI & Contact heat & S1, IC, ACC, Th, PFC, M1, PMC, PP, BG \\
\hline Tracey et al. (2000) & fMRI & Cold & S1, IC, ACC, Th, PFC, M1, PMC, PP, BG \\
\hline Becerra et al. (2001) & fMRI & Contact heat & S1, IC, Th, CB, Amyg, PAG, VT \\
\hline Casey et al. (2001) & PET & Contact heat & S1, S2, IC, ACC, Th, CB \\
\hline Coghill et al. (2001) & PET & Contact heat & S1, S2, IC, ACC, Th, PFC, CB, BG \\
\hline Fulbright et al. (2001) & fMRI & Cold & $\mathrm{S} 1, \mathrm{~S} 2, \mathrm{ACC}, \mathrm{IC}, \mathrm{Th}, \mathrm{PFC}$ \\
\hline Hofbauer et al. (2001) & PET & Contact heat & S1, S2, IC, ACC \\
\hline Ladabaum et al. (2001) & PET & Gastric distension & IC, Th, ACC, BG, CB, occipital \\
\hline Bingel et al. (2002) & fMRI & Laser heat & BG, CB, Amyg, BS, Hippo \\
\hline Buchel et al. (2002) & fMRI & Laser heat & S1, S2, IC, Amyg \\
\hline Buchel et al. (2002) & fMRI & Laser heat & $\mathrm{ACC}$ \\
\hline Chang et al. (2002) & fMRI & Contact heat & $\mathrm{S} 1, \mathrm{~S} 2$ \\
\hline Davis et al. (2002) & fMRI & Cold prickle & S2, IC, ACC, Th, PFC, PMC, BG \\
\hline Fabri et al. (2002) & fMRI & Cutaneous pressure & S1, S2, IC, ACC \\
\hline Korotkov et al. (2002) & PET & Muscular hypertonic saline & $\mathrm{IC}, \mathrm{BG}$ \\
\hline Kurata et al. (2002) & fMRI & Contact heat & S2, IC, ACC, PFC, BG, PMC \\
\hline Niddam et al. (2002) & fMRI & Muscular electric shock & S2, IC, ACC, Th, PFC, BG, PCC, \\
\hline Peyron et al. (2002) & PET and fMRI & Laser heat & $\mathrm{S} 2, \mathrm{IC}$ \\
\hline Petrovic et al. (2002b) & PET & Cold & S1 \\
\hline Bingel et al. (2003) & fMRI & Laser heat & S1, S2, IC, Th \\
\hline
\end{tabular}


eTable 1 (continued)

\begin{tabular}{llll}
\hline Source & Scan type & Pain stimulus & Areas activated \\
\hline Helmchen et al. (2003) & fMRI & Contact heat & CB \\
Rolls et al. (2003) & fMRI & Cutaneous pressure & IC, ACC, PFC \\
Strigo et al. (2003) & fMRI & Contact heat & S1, S2, IC, ACC, Th, PFC, BG, CB \\
Strigo et al. (2003) & fMRI & Esophagus distension & S1, S2, IC, ACC, Th, BG, CB \\
\hline
\end{tabular}

Abbreviations: S1, primary somatosensory cortex; S2, secondary somatosensory cortex; IC, insular cortex; ACC, anterior cingulate; Th, thalamus; PFC, prefrontal cortex; BG, basal ganglia; CB, cerebellum; PCC, posterior cingulate; PMC, premotor cortex; BS, brainstem; Amyg, amygdala; Hippo, hippocampus; PAG, periaqueductal gray; VT, ventral tegmentum; M1, primary motor cortex; PPC, posterior parietal cortex; PMC, premotor cortex; PVG, periventricular gray; SMA, supplementary motor area; Hyp, hypothalamus.

Regions showing decreases with pain are indicated in italic.

eTable 2

Pain somatotopic organization

\begin{tabular}{|c|c|c|c|c|c|}
\hline Source & Scan type & Pain stimulus & Stimulated sites & Brain region & Organization \\
\hline Tarkka and Treede (1993) & EEG & Laser heat & Hand, foot & $\mathrm{S} 1$ & Foot medial, hand lateral \\
\hline Tarkka and Treede (1993) & EEG & Laser heat & Hand, foot & $\mathrm{S} 2, \mathrm{ACC}$ & No organization \\
\hline Andersson et al. (1997) & PET & Capsaicin & Hand, foot & $\mathrm{S} 1$ & Foot medial, hand lateral \\
\hline $\mathrm{Xu}$ et al. (1997) & PET & Laser heat & Hand, foot & $\mathrm{S} 2$ & No organization \\
\hline $\mathrm{Xu}$ et al. (1997) & PET & Laser heat & Hand, foot & IC & No organization \\
\hline DaSilva et al. (2002) & fMRI & Contact heat & $\mathrm{V} 1, \mathrm{~V} 2, \mathrm{~V} 3$, thumb & BS & rostrocaudal \\
\hline DaSilva et al. (2002) & fMRI & Contact heat & $\mathrm{V} 1, \mathrm{~V} 2, \mathrm{~V} 3$, thumb & $\mathrm{Th}$ & Medio-lateral \\
\hline DaSilva et al. (2002) & fMRI & Contact heat & $\mathrm{V} 1, \mathrm{~V} 2, \mathrm{~V} 3$ & $\mathrm{~S} 1$ & Rostro-caudal, medio-lateral \\
\hline Strigo et al. (2003) & fMRI & $\begin{array}{l}\text { Contact heat and } \\
\text { esophagus distension }\end{array}$ & Chest, esophagus & $\mathrm{S} 1$ & Medio-lateral \\
\hline Vogel et al. (2003) & EEG & Laser heat & Face, hand & $\mathrm{S} 2$ & Face anterior, hand posterior \\
\hline
\end{tabular}

See eTable 1 for abbreviations. V1, V2, and V3 are the three branches of the trigeminal nerve.

ity of the earlier PET studies (note that this bias is naturally adjusted by the number of PET studies included in the comparison between normal subjects and patients, see below).

\subsubsection{Defining a pain network: pain-evoked potentials and magnetic fields}

The first evoked potentials in response to brief painful stimuli were published in the 1960s (Spreng and Ichioka, 1964) and corresponding magnetic fields in the 1980s (Hari et al., 1983). Detailed analysis of the cortical representation of pain by electrophysiological measures (see eTable 4), however, was greatly advanced by the independent evidence from the first PET studies (Jones et al., 1991; Talbot et al., 1991). Subsequent EEG and MEG source analyses documented electrical activity in S1, S2, and its vicinity in the frontoparietal operculum, IC or adjacent anterior temporal lobe, and ACC (Joseph et al., 1991; Tarkka and Treede, 1993; Kakigi et al., 1995; Bromm and Chen, 1995; Ploner et al., 1999; Dowman and Schell, 1999; Valeriani et al., 2003). Intracranial recordings as part of the presurgical evaluation in epilepsy patients confirmed the sources in S1, S2, IC, and ACC (Lenz et al., 1998a,b; Kanda et al., 2000; Vogel et al., 2003).

Our meta-analysis (Table 2) indicates that there are important differences between EEG and MEG based studies regarding the detection of responses to painful stimuli in S1, S2, and ACC: MEG is more sensitive to determine the sources in S1 and S2 that are oriented tangentially to the scalp, while the radially oriented current flow in ACC activity is more frequently detected by EEG. The MEG technique is intrinsically insensitive to radially oriented current flow. EEG source analysis is sensitive to any orientation of the underlying dipole, which on the other hand may make it more difficult to separate multiple sources than in the restricted view of MEG. Very few EEG or MEG studies demonstrate activity in IC and neither method shows activation of Th or PFC. IC and Th may be missed due to their position deep inside the brain, since location accuracy of both techniques deteriorates with increasing distance from the scalp. Compared with hemodynamic imaging studies, electrical and magnetic recordings are highly sensitive to describe activity in the $\mathrm{S} 2$ region, but outside this region hemodynamic methods seem to be more sensitive.

The temporal resolution of EEG and MEG, however, is unsurpassed. For example, the dual pain sensation elicited by a single brief painful stimulus that is due to the different conduction times in nociceptive A- and Cfibers (about $1 \mathrm{~s}$ difference) is reflected in two sequential brain activations in EEG and MEG recordings from S1, S2 and ACC (Bromm and Treede, 1983; Arendt-Nielsen, 1990; Bragard et al., 1996; Magerl et al., 1999; Opsommer et al., 2001; Tran et al., 2002;Ploner et al., 2002a; 
eTable 3

Psychological modulation of pain

\begin{tabular}{|c|c|c|c|c|}
\hline Source & Scan type & Task & Brain regions & Findings \\
\hline Rainville et al. (1997) & PET & $\begin{array}{l}\text { Hypnotic suggestions for } \\
\text { unpleasantness }\end{array}$ & $\mathrm{ACC}$ & $\begin{array}{l}\text { Pain-evoked activity modulated by suggestions for } \\
\text { increased or decreased unpleasantness }\end{array}$ \\
\hline Bushnell et al. (1999) & PET & Attention, distraction & S1 & $\begin{array}{l}\text { Pain-evoked activity reduced when attending } \\
\text { auditory stimulus }\end{array}$ \\
\hline Hsieh et al. (1999b) & PET & Anticipation & PFC, ACC, PAG & Activated during anticipation of pain \\
\hline Ploghaus et al. (1999) & fMRI & Anticipation & $\mathrm{PFC}, \mathrm{IC}, \mathrm{CB}$ & Activated during anticipation of pain \\
\hline Petrovic et al. (2000) & PET & Attention, distraction & PFC, PAG & $\begin{array}{l}\text { Pain-evoked activity reduced when performing } \\
\text { cognitive task }\end{array}$ \\
\hline Petrovic et al. (2000) & PET & Attention, distraction & PFC & $\begin{array}{l}\text { Pain-evoked activity increased when performing } \\
\text { cognitive task }\end{array}$ \\
\hline Faymonville et al. (2000) & PET & $\begin{array}{l}\text { Hypnotic suggestions for } \\
\text { reduced pain }\end{array}$ & $\mathrm{ACC}$ & $\begin{array}{l}\text { Pain-evoked activity reduced during hypnotic } \\
\text { suggestions }\end{array}$ \\
\hline Ploghaus et al. (2000) & fMRI & Expectation & Hippo, PFC, CB & Activated during expected pain that was omitted \\
\hline Sawamoto et al. (2000) & fMRI & Expectation & $\mathrm{S} 2, \mathrm{IC}, \mathrm{ACC}$ & $\begin{array}{l}\text { Enhanced activation to warm stimulus when } \\
\text { expecting pain }\end{array}$ \\
\hline Frankenstein et al. (2001) & fMRI & Attention, distraction & $\mathrm{ACC}$ & $\begin{array}{l}\text { Verbal task distracter reduced pain-evoked ACC } \\
\text { area } 24 \text { activation, and activated area } 32\end{array}$ \\
\hline Hofbauer et al. (2001) & PET & $\begin{array}{l}\text { Hypnotic suggestions for } \\
\text { pain sensation }\end{array}$ & S1 & $\begin{array}{l}\text { Pain-evoked activation modulated by suggestions } \\
\text { for increased or decreased pain sensation }\end{array}$ \\
\hline Longe et al. (2001) & fMRI & Attention, distraction & ACC, $\mathrm{IC}, \mathrm{Th}$ & $\begin{array}{l}\text { Distracting vibratory stimulus reduced pain- } \\
\text { evoked activity }\end{array}$ \\
\hline Ploghaus et al. (2001) & fMRI & Anxiety & $\begin{array}{l}\text { Hippo, peri-genual } \\
\text { ACC, mid-IC }\end{array}$ & Anxiety amplified pain-related responses \\
\hline Bantick et al. (2002) & fMRI & Attention, distraction & $\mathrm{ACC}, \mathrm{IC}, \mathrm{Th}$ & $\begin{array}{l}\text { Pain-evoked activity reduced during Stroop } \\
\text { counting task }\end{array}$ \\
\hline Bantick et al. (2002) & fMRI & Attention, distraction & ACC, PFC & Activated during Stroop counting task distraction \\
\hline Brooks et al. (2002) & fMRI & Attention, distraction & IC & $\begin{array}{l}\text { Pain-evoked activity reduced when attending } \\
\text { visual stimulus }\end{array}$ \\
\hline Petrovic et al. (2002a) & PET & Placebo & Rostral ACC & Activated during placebo analgesia \\
\hline Porro et al. (2002) & fMRI & Anticipation & $\mathrm{S} 1$, rostral ACC & Modulated during anticipation of pain \\
\hline Tracey et al. (2002) & fMRI & Attention, distraction & PAG & Activated during distraction from pain \\
\hline Phillips et al. (2003) & fMRI & Emotions & ACC, IC & $\begin{array}{l}\text { Larger pain-evoked activation during fearful faces } \\
\text { than neutral faces }\end{array}$ \\
\hline
\end{tabular}

See eTable 1 for abbreviations.

Iannetti et al., 2003). The first, A fiber mediated, brain activation can further be subdivided into an early (100-200 ms after stimulus onset) and a late EEG/ MEG response (beyond $200 \mathrm{~ms}$ latency; Treede et al., 1988). EEG mapping studies (Kunde and Treede, 1993; Miyazaki et al., 1994), source analysis (Tarkka and Treede, 1993; Valeriani et al., 1996; Ploner et al., 1999), and intracranial recordings (Lenz et al., 1998a; Frot et al., 1999) show that the earliest pain-induced brain activity originates in the vicinity of S2. In contrast, tactile stimuli activate this region only after processing in the primary somatosensory cortex (Ploner et al., 2000). The adjacent dorsal IC is activated slightly but significantly later than the operculum (Frot and Mauguiere, 2003). These observations support the suggestion derived from anatomical studies that the $\mathrm{S} 2$ region and adjacent IC are a primary receiving area for nociceptive input to the brain (Apkarian and Shi, 1994; Craig, 2002).

The sources for later EEG and MEG signals (beyond $200 \mathrm{~ms}$ peak latency) have been localized in ACC, close to the border between its anterior and posterior parts
(Bentley et al., 2002; Peyron et al., 2002). This relatively posterior location may be related to the phasic nature of the stimuli used. Late EEG and MEG signals correlate more closely with perceived pain intensity than with stimulus strength (Beydoun et al., 1993). This correlation pattern as well as the long latency of its activation suggests a role of ACC in cognitive-evaluative stages of pain processing.

All EEG and MEG studies in eTable 4 exploit the high signal-to-noise ratio of evoked potentials. Changes in ongoing EEG patterns or coherences following tonic painful stimuli, in contrast, are more subtle and their specificity for nociceptive processing is still being debated (Backonja et al., 1991; Ferracuti et al., 1994; Chen et al., 1998; Chang et al., 2002).

\subsubsection{Neural correlates of different types of pain}

Cortical activation patterns related to many types of painful stimuli have now been studied. As shown in eTable 1, these stimuli include cutaneous noxious cold, muscle stimulation using electric shock or hypertonic saline, capsaicin, colonic distension, rectal distension, 
eTable 4

Brain areas activated for pain in EEG and MEG source analysis studies

\begin{tabular}{|c|c|c|c|}
\hline Source & Scan type & Pain stimulus & Areas activated \\
\hline Joseph et al. (1991) & MEG & Electrical, skin & $\mathrm{S} 1$, frontal operculum \\
\hline Tarkka and Treede (1993) & EEG & Radiant heat & $\mathrm{S} 1, \mathrm{~S} 2, \mathrm{ACC}$ \\
\hline Bromm and Chen (1995) & EEG & Radiant heat & $\mathrm{S} 2, \mathrm{ACC}$, frontal lobe \\
\hline Kakigi et al. (1995) & MEG & Radiant heat & $\mathrm{S} 2$ \\
\hline Kitamura et al. (1995) & MEG & Electrical, skin & $\mathrm{S} 1, \mathrm{~S} 2$ \\
\hline Valeriani et al. (1996) & EEG & Radiant heat & $\mathrm{S} 2$, IC-anterior temporal lobe, ACC \\
\hline Hari et al. (1997) & MEG & Acid, nasal mucosa & $\mathrm{S} 1, \mathrm{~S} 2$ \\
\hline Kitamura et al. (1997) & MEG & Electrical, nerve & $\mathrm{S} 1, \mathrm{~S} 2, \mathrm{ACC}$ \\
\hline Watanabe et al. (1998) & MEG & Radiant heat & S2, medial anterior temporal lobe \\
\hline Arendt-Nielsen et al. (1999) & MEG & Mechanical, skin & $\mathrm{S} 2$ \\
\hline Dowman and Schell (1999) & EEG & Electrical, nerve & ACC, SMA \\
\hline Loose et al. (1999) & MEG & Mechanical, esophagus & $\mathrm{S} 2$, frontal lobe \\
\hline Ploner et al. (1999) & MEG & Radiant heat & $\mathrm{S} 1, \mathrm{~S} 2$ \\
\hline Yamasaki et al. (1999) & MEG & Radiant heat & $\mathrm{S} 2-\mathrm{IC}, \mathrm{ACC}$ \\
\hline Druschky et al. (2000) & MEG & Mechanical, skin & $\mathrm{S} 1, \mathrm{~S} 2, \mathrm{ACC}$ \\
\hline Kanda et al. (2000) & MEG & Radiant heat & $\mathrm{S} 1, \mathrm{~S} 2$ \\
\hline Ploner et al. (2000) & MEG & Radiant heat & $\mathrm{S} 1, \mathrm{~S} 2$ \\
\hline Valeriani et al. (2000) & EEG & Radiant heat & S2, ACC, IC-temporal cortex, \\
\hline Bentley et al. (2002) & EEG & Radiant heat & Anterior IC, PP, PCC \\
\hline Dowman (2001) & EEG & Electrical, nerve & ACC, SMA \\
\hline Ninomiya et al. (2001) & MEG & Electrical, skin & $\mathrm{S} 1, \mathrm{~S} 2, \mathrm{ACC}$ \\
\hline Opsommer et al. (2001) & EEG & Radiant heat & $\mathrm{S} 2, \mathrm{ACC}$ \\
\hline Timmermann et al. (2001) & MEG & Radiant heat & $\mathrm{S} 1, \mathrm{~S} 2$ \\
\hline Bentley et al. (2002) & EEG & Radiant heat & Caudal ACC \\
\hline Inui et al. (2002) & MEG & Electrical, skin & $\mathrm{S} 1, \mathrm{~S} 2$ \\
\hline Maihofner et al. (2002) & MEG & Noxious cold & $\mathrm{S} 2$, posterior $\mathrm{IC}, \mathrm{ACC}$ \\
\hline Ploner et al. (2002b) & MEG & Radiant heat & $\mathrm{S} 1, \mathrm{~S} 2, \mathrm{ACC}$ \\
\hline Torquati et al. (2002) & MEG & Electrical, nerve & $\mathrm{S} 1, \mathrm{~S} 2$ \\
\hline Tran et al. (2002) & MEG & Radiant heat & $\mathrm{S} 1, \mathrm{~S} 2$ \\
\hline Valeriani et al. (2002) & EEG & Contact heat & $\mathrm{S} 2, \mathrm{ACC}$, anterior temporal lobe \\
\hline
\end{tabular}

See eTable 1 for abbreviations.

gastric distension, esophageal distension, ischemia, cutaneous electric shock, ascorbic acid, laser heat, as well as an illusion of pain evoked by combinations of innocuous temperatures. As observed when comparing data across studies of cutaneous contact heat stimulation, these varying types of pain produce many similarities and differences in cortical and sub-cortical sites that show significant activation. The differences could be attributed to technical and statistical differences, as discussed above, varying pain intensities, different cognitive states or variations specifically related to the modality of pain. Without comparing the different modalities in the same subjects and acquiring detailed evaluations of independent aspects of the individuals' cognitive state, the source of the variability in results cannot be determined. For example, Strigo et al. (2003) compared in the same subjects cortical activations produced by esophageal distension and contact heat on the chest, with the perceived pain intensity matched between stimuli for each subject. For these subjects the visceral and cutaneous pain both led to activations in S1, S2, ACC and IC, but the exact loci within the regions differed for the two types of pain, thus supporting the idea that there may be sub-regional differences in the processing of different types of pain. eTable 1 also shows many sim- ilarities across these studies. The ACC appears to have a particularly robust activation across different stimulus modalities and measurement techniques $(81 \%$ with fMRI, 94\% with PET, 100\% with EEG, Table 1), although the locus of this activation varies among studies. Vogt et al. (1996) initially subdivided the ACC into four components and suggested that affective reactions to pain would be localized to perigenual (or rostral) ACC, while cognitive processes to mid-cingulate (at or around supplementary motor region) activations. Recently, Derbyshire (2003) further subdivided ACC to six components, proposing differential responses to different visceral stimuli (for an alternative viewpoint, see Peyron et al., 2000). In earlier studies S1 cortex showed a less reliable pain-related activation (see Bushnell et al., 1999), even though single nociceptive neurons have been identified in this region in monkey (Kenshalo and Isensee, 1983; Kenshalo et al., 1988). The current analysis shows that similar numbers of studies report $\mathrm{S} 1$ activity as S2 activity using PET or fMRI imaging methods; with an overall rate of reporting being $75 \%$ for both (Table 2). Previous reviews argued that the lower incidence in observing activity in $\mathrm{S} 1$ as compared to S2 was most likely due to technical difficulties (Bushnell et al., 1999; Peyron et al., 2000); mainly due to differ- 
eTable 5

Brain areas activated in clinical pain studies

\begin{tabular}{|c|c|c|c|c|}
\hline Source & Scan type & Patient group & Stimulus & Areas activated \\
\hline Di Piero et al. (1991) & PET & Cancer pain & Pre- vs. post-cordotomy pain relief & Th blood flow decreased during cancer pain \\
\hline Hsieh et al. (1996) & PET & Cluster headache & Nitroglycerin & IC, ACC, PFC, BG, PP, M1, occipital, temporal \\
\hline May et al. (1998) & PET & Cluster headache & Nitroglycerin & IC, ACC, Th, CB, BG, Hyp \\
\hline May et al. (2000) & PET & Cluster headache & Nitroglycerin & S1/M1, IC, Th, ACC, PFC, BG, Нyp \\
\hline May et al. (2000) & PET & Cluster headache & Nitroglycerin & IC, Th, ACC, PFC, BG, temporal \\
\hline Weiller et al. (1995) & PET & Migraine & Spontaneous migraine & Cingulate, auditory, and visual association \\
\hline Andersson (1998) & PET & Migraine & Aura, headache, and post Sumatriptan & Primary visual cortex blood flow decreased during headache \\
\hline Cutrer et al. (1998) & Perfusion MRI & Migraine & Visual aura & $\begin{array}{l}\text { Contralateral occipital decreased blood flow and blood } \\
\text { volume }\end{array}$ \\
\hline Cao et al. (1999) & fMRI & Migraine & $\begin{array}{l}\text { Visually triggered headache; } \\
\text { Checkerboard stimulus }\end{array}$ & Occipital cortex decreased stimulus responses \\
\hline Sanchez et al. (1999) & Perfusion MRI & Migraine & $\begin{array}{l}\text { Spontaneous migraine, with or without } \\
\text { aura }\end{array}$ & Occipital cortex decreased blood flow during aura \\
\hline Rosen et al. (1994) & PET & Cardiac pain & Dobutamine & Th, PFC, BS, Hippo \\
\hline Rosen et al. (1996) & PET & Cardiac pain & Dobutamine & Th, PFC, BS, Hippo \\
\hline Rosen et al. (1996) & PET & Cardiac pain & Dobutamine & Th, ACC, PFC, Hyp, occipital \\
\hline Rosen et al. (1996) & PET & Cardiac pain & Dobutamine & ACC, PFC, temporal \\
\hline Rosen et al. (1996) & PET & Cardiac pain & Dobutamine & IC, Th, PFC, BG, CB \\
\hline Rosen et al. (1996) & PET & Cardiac pain, syndrome $\mathrm{X}$ & Dobutamine & $\mathrm{IC}, \mathrm{PFC}$ \\
\hline Rosen et al. (2002) & PET & Cardiac pain, syndrome $\mathrm{X}$ & Dobutamine & IC, Th, PFC, BG, CB \\
\hline Silverman et al. (1997) & PET & IBS & Rectal distension pain, pain anticipation & $\begin{array}{l}\mathrm{PFC} \text {; in normal subjects } \mathrm{ACC} \text { related to pain; in } I B S A C C \\
\text { is not related to pain }\end{array}$ \\
\hline Mertz et al. (2000) & fMRI & IBS & $\begin{array}{l}\text { Rectal distension } 15,30,50 \mathrm{mmHg} ; 50 \\
\mathrm{mmHg} \text { is painful }\end{array}$ & $\begin{array}{l}\text { ACC, Th for pain; in normal subjects ACC related to pain; } \\
\text { in IBS ACC is not related to perceived pain }\end{array}$ \\
\hline Naliboff et al. (2001) & PET & IBS & $\begin{array}{l}\text { Rectosigmoid distension pain, pain } \\
\text { anticipation }\end{array}$ & ACC, PFC, PCC \\
\hline Bonaz et al. (2002) & fMRI & IBS & Rectal distension & None \\
\hline Berman et al. (2002) & PET & IBS & Gastric distension, placebo-Alosetran & ACC, PFC, Hyp, BG, Amyg \\
\hline Bernstein et al. (2002) & fMRI & IBS, IBD & Rectal distension & $\mathrm{ACC}$ \\
\hline Wik et al. (1999) & PET & FM & Patients - normals & PCC PFC, parieto-temporal decreased \\
\hline Gracely et al. (2002) & fMRI & FM & Mechanical pressure & $\mathrm{S} 1, \mathrm{~S} 2, \mathrm{IC}, \mathrm{PP}, \mathrm{BG} S 2, T h, P F C, B G$ decreased \\
\hline Gracely et al. (2002) & fMRI & FM & $\begin{array}{l}\text { Mechanical pressure, equated } \\
\text { perceptually }\end{array}$ & S1, S2, IC, ACC, PP, CB \\
\hline Fukumoto et al. (1999) & SPECT & CRPS & Blood flow & $\begin{array}{l}\text { Contralateral/ipsilateral Th hyperperfusion in early CRPS; } \\
\text { hypoperfusion in prolonged CRPS }\end{array}$ \\
\hline Apkarian et al. (2001) & fMRI & CRPS & Contact heat, sympathetic blocks & CRPS pain associated with ACC, PFC; Th decreased \\
\hline Willoch et al. (2000) & PET & Phantom pain & Phantom pain induced by hypnosis & S1/M1, ACC, Th, PFC \\
\hline Iadarola et al. (1998) & PET & Normal subjects, capsaicin injury & Allodynia - touch & S1, S2, PFC, BG, CB, BS, Нippo \\
\hline Baron et al. (1999) & fMRI & Normal subjects, capsaicin injury & Allodynia vs. touch & PFC; no change in S1, S2, ACC \\
\hline Witting et al. (2001) & PET & Normal subjects, capsaicin injury & Allodynia - touch & S1, IC, Th, PFC, CB \\
\hline Lorenz et al. (2002) & PET & Normal subjects, capsaicin injury & Allodynia - heat, equated perceptually & IC, Th, PFC, BG, BS \\
\hline Hsieh et al. (1995) & PET & Mono-neuropathy & Painful state - nerve block & IC, ACC, PFC, PP Th decreased \\
\hline Iadarola et al. (1995) & PET & Neuropathy & Neuropathy vs. normal subjects & Th decreased \\
\hline Petrovic et al. (1999) & PET & Mono-neuropathy & Allodynia - rest & S1, S2, IC, ACC, Th, BS, CB \\
\hline Duncan et al. (1998) & PET & Neuropathy & Deep brain stimulation $\mathrm{Th}$ & $\mathrm{S} 1, \mathrm{~S} 2, \mathrm{IC}, \mathrm{Th}, \mathrm{PFC}$ \\
\hline Davis et al. (2000) & fMRI & Chronic pain & Deep brain stimulation Th & ACC not related to pain relief \\
\hline
\end{tabular}




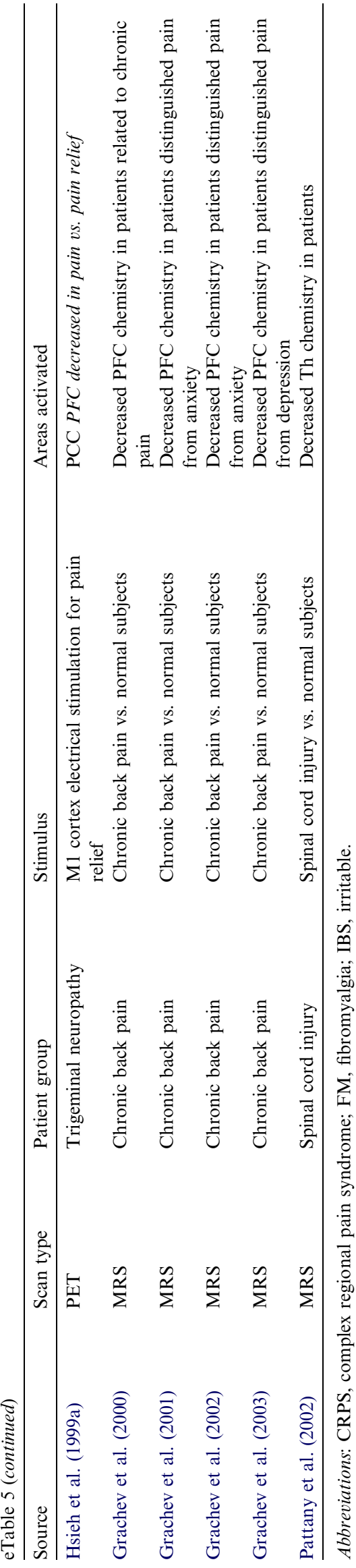

ences in spatial extent of activity as compared to spatial resolution of brain imaging techniques. It seems that more recent studies have overcome such difficulties. Unexpectedly, IC shows the highest incidence of activity ( $94 \%$ in Table 2). This area of the cortex is anatomically heterogeneous (Mesulam and Mufson, 1982) and activations in its posterior portion may be more related to sensory aspects of pain. The more anterior IC is anatomically more continuous with PFC and as a result it may be more important in emotional, cognitive and memory related aspects of pain perception.

\subsection{Somatotopic organization of pain in the brain}

Although studies of hemodynamic changes related to pain provide imprecise spatial resolution, ranging from 2 to $15 \mathrm{~mm}$, some information has been obtained related to somatotopic organization of pain in the human brain. eTable 2 shows that such organization has been primarily observed in S1 cortex, with the organization following the same somatotopy as observed for tactile input. No clear somatotopic organization has been reported for painful input into S2 cortex, but a number of fMRI and MEG studies have found a topographic organization of S2 for non-painful somatosensory input (Maeda et al., 1999; Del Gratta et al., 2000; Disbrow et al., 2000; Del Gratta et al., 2002), suggesting that such organization may also exist for nociceptive input.

Within S1, somatotopic arrangement of EEG and MEG sources was found to be consistent with the tactile homunculus for hand and foot stimulation (Tarkka and Treede, 1993; Ploner et al., 1999), while the face region was too far lateral to be distinguishable from S2 and IC (Bromm and Chen, 1995). Within the S2-IC region, the face was represented anterior of the foot (Vogel et al., 2003), which is in contrast to the mediolateral tactile representation in that region. This difference in somatotopy argues for a separation of tactile and nociceptive areas within the region.

\subsection{Psychological modulation of pain}

The advent of human brain imaging has provided an important new avenue for understanding the neural basis of psychological modulation of pain. Brain imaging experiments have explored mechanisms underlying attentional and emotional modulation of pain, as well as activity related to expectation and anticipation of pain (see eTable 3). Studies examining the effects of distraction show modulation of pain-evoked activity in S1, ACC, IC, and Th. Other regions, including PAG, parts of ACC, and orbitofrontal cortex (within PFC) are activated when subjects are distracted from pain, suggesting that these regions may be involved in the modulatory circuitry related to attention. Hypnotic suggestions also alter pain-evoked activity, but the specific regions 
Table 2

Frequency of brain areas active during pain in normal subjects, parceled by imaging modality

\begin{tabular}{|c|c|c|c|c|c|c|}
\hline & ACC & S1 & S2 & IC & Th & PFC \\
\hline \multirow[t]{2}{*}{32 PET studies } & $28 / 30$ & $18 / 26$ & $17 / 25$ & $22 / 25$ & $16 / 19$ & $9 / 23$ \\
\hline & $94 \%$ & $69 \%$ & $68 \%$ & $88 \%$ & $84 \%$ & $39 \%$ \\
\hline \multirow[t]{2}{*}{36 fMRI studies } & $22 / 27$ & $19 / 25$ & $21 / 26$ & $23 / 23$ & $13 / 16$ & $14 / 20$ \\
\hline & $81 \%$ & $76 \%$ & $81 \%$ & $100 \%$ & $81 \%$ & $70 \%$ \\
\hline \multirow[t]{2}{*}{10 EEG studies } & $10 / 10$ & $1 / 10$ & $6 / 10$ & $3 / 10$ & $0 / 10$ & $0 / 10$ \\
\hline & $100 \%$ & $10 \%$ & $60 \%$ & $30 \%$ & $0 \%$ & $0 \%$ \\
\hline \multirow[t]{2}{*}{20 MEG studies } & $5 / 20$ & $14 / 20$ & $19 / 20$ & $2 / 20$ & $0 / 20$ & $0 / 20$ \\
\hline & $25 \%$ & $70 \%$ & $95 \%$ & $10 \%$ & $0 \%$ & $0 \%$ \\
\hline Comparison between PET and fMRI studies & $P>0.23$ & $P>0.75$ & $P>0.34$ & $P>0.23$ & $P=1.0$ & $P=0.07$ \\
\hline Comparison between EEG and MEG studies & $P<0.001$ & $P=0.003$ & $P=0.031$ & $P=0.3$ & $P=1.0$ & $P=1.0$ \\
\hline Comparison between PET/fMRI and EEG/MEG studies & $P<0.001$ & $P=0.056$ & $P=0.42$ & $P<0.001$ & $P<0.001$ & $P<0.001$ \\
\hline
\end{tabular}

Numerator is number of studies where the area was reported activated; denominator is total number of studies where the area was investigated. ACC, anterior cingulate; S1, primary somatosensory cortex; S2, secondary somatosensory cortex; IC, insular cortex; Th, thalamus; PFC, prefrontal cortex. $P$ values are based on Fisher's exact statistics contrasting incidence for each area.

Table 3

Frequency of brain areas active during pain in normal subjects as compared to patients with clinical pain conditions

\begin{tabular}{|c|c|c|c|c|c|c|}
\hline & ACC & S1 & S2 & IC & Th & $\mathrm{PFC}$ \\
\hline Pain in normal subjects in 68 studies & $\begin{array}{l}47 / 54 \\
87 \%\end{array}$ & $\begin{array}{l}39 / 52 \\
75 \%\end{array}$ & $\begin{array}{l}38 / 51 \\
75 \%\end{array}$ & $\begin{array}{l}45 / 48 \\
94 \%\end{array}$ & $\begin{array}{l}28 / 35 \\
80 \%\end{array}$ & $\begin{array}{l}23 / 42 \\
55 \%\end{array}$ \\
\hline Clinical pain conditions in 30 studies & $\begin{array}{l}13 / 29 \\
45 \%\end{array}$ & $\begin{array}{l}7 / 25 \\
28 \%\end{array}$ & $\begin{array}{l}5 / 25 \\
20 \%\end{array}$ & $\begin{array}{l}15 / 26 \\
58 \%\end{array}$ & $\begin{array}{l}16 / 27 \\
59 \%\end{array}$ & $\begin{array}{l}21 / 26 \\
81 \%\end{array}$ \\
\hline Comparison between pain in normal subjects and in clinical conditions & $P<0.001$ & $P<0.001$ & $P<0.001$ & $P<0.001$ & $P=0.095$ & $P=0.038$ \\
\hline
\end{tabular}

Incidence values are based on PET, SPECT and fMRI studies. For details, see Table 1.

$P$ values are based on Fisher's exact statistics contrasting incidence for each area.

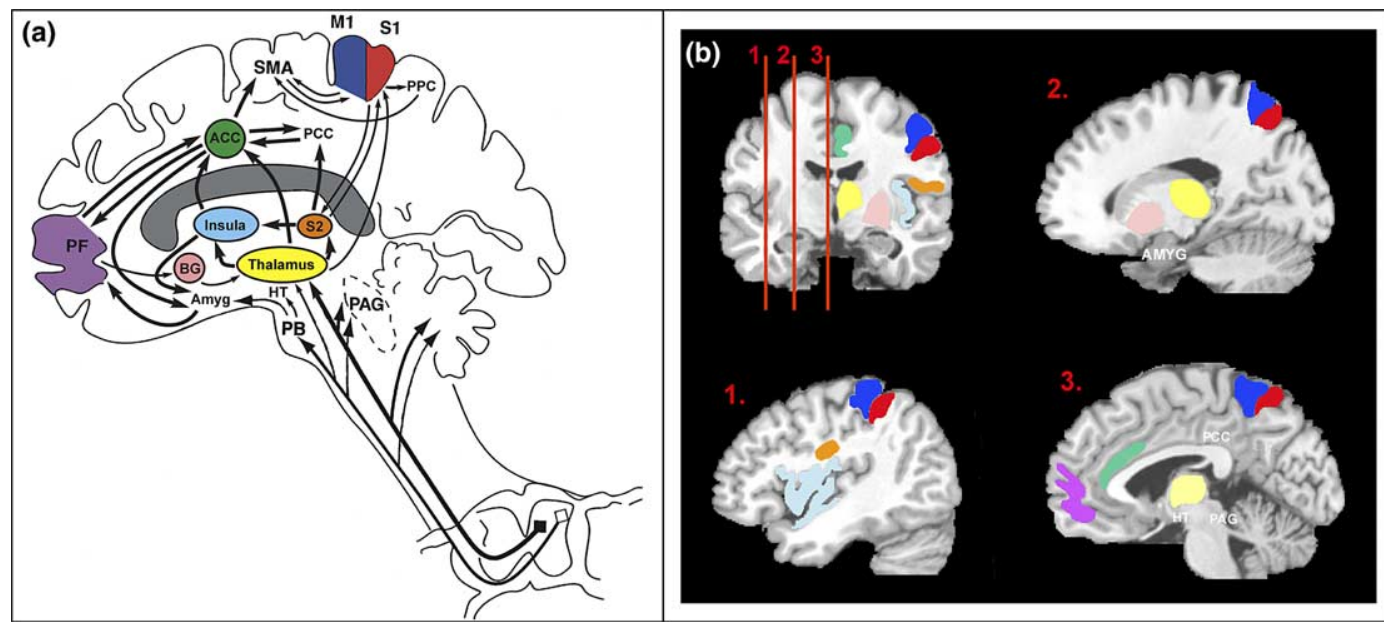

Fig. 1. Cortical and sub-cortical regions involved in pain perception, their inter-connectivity and ascending pathways. Locations of brain regions involved in pain perception are color-coded in a schematic drawing and in an example MRI. (a) Schematic shows the regions, their inter-connectivity and afferent pathways. The schematic is modified from Price (2000) to include additional brain areas and connections. (b) The areas corresponding to those shown in the schematic are shown in an anatomical MRI, on a coronal slice and three sagittal slices as indicated on the coronal slice. The six areas used in meta-analysis are primary and secondary somatosensory cortices (S1, S2, red and orange), anterior cingulate (ACC, green), insula (blue), thalamus (yellow), and prefrontal cortex (PF, purple). Other regions indicated include: primary and supplementary motor cortices (M1 and SMA), posterior parietal cortex (PPC), posterior cingulate (PCC), basal ganglia (BG, pink), hypothalamus (HT), amygdala (AMYG), parabrachial nuclei (PB), and periaqueductal gray (PAG). 
involved depend on the nature of the suggestions (Rainville et al., 1997; Faymonville et al., 2000; Hofbauer et al., 2001). Similarly, emotional state can influence pain perception, and a recent study shows that negative emotional states enhance pain-evoked activity in limbic regions, such as ACC and IC (Phillips et al., 2003). Finally, the anticipation or expectation of pain can activate pain-related areas, regions such as S1, ACC, PAG, IC, PFC and cerebellum, in the absence of a physical pain stimulus (Beydoun et al., 1993; Ploghaus et al., 1999; Hsieh et al., 1999b; Sawamoto et al., 2000; Porro et al., 2002; Villemure and Bushnell, 2002).

EEG and MEG studies have shown that cognitive modulation of pain by attention involves early sensory processing in S2-IC (Legrain et al., 2002; Nakamura et al., 2002) and later processing in ACC (Beydoun et al., 1993; Kanda et al., 1996; Siedenberg and Treede, 1996; Garcia-Larrea et al., 1997). Attentional modulation may in part reflect a change in cortical processing and in part a decrease in ascending afferent input from the spinal cord due to activation of descending noxious inhibitory controls. EEG signals can document this type of inhibitory control in humans (Plaghki et al., 1994; Reinert et al., 2000; Hoshiyama and Kakigi, 2000). In contrast to distraction paradigms, hypnotic suggestion influenced pain perception (Arendt-Nielsen et al., 1990) but did not affect the EEG signals (Meier et al., 1993; Friederich et al., 2001). Anticipation of painful stimuli, or priming with pain-related adjectives, significantly enhanced the EEG signals (Miyazaki et al., 1994; Dillmann et al., 2000). In turn, interference of chronic pain with the performance of cognitive functions has also been shown in EEG studies (Lorenz and Bromm, 1997; Lorenz et al., 1997).

\subsection{Measures of neuroreceptors and neurotransmitters}

Two main approaches have been used to study the neurochemistry of pain: examination of brain metabolic function in response to relevant pharmacological agents, and direct measurement of receptors for neurotransmitters. The latter involves the use of radiolabeled pharmaceuticals introduced at tracer doses. Acquisition of data over time, as the radiotracer binds to specific receptor sites, together with appropriate kinetic models, allows for the quantification of receptor sites and enzyme function in human subjects with PET or SPECT. The majority of studies have examined the endogenous opioid system and its receptors, with the $\mu$-opioid receptor type being the one primarily mediating the effect of clinically utilized opiate medications. More recently, other neurotransmitter systems, such as dopamine, have also been examined.

The exogenous administration of $\mu$-opioid receptor agonist drugs has been shown to dose-dependently increase $\mathrm{rCBF}$, and by extension metabolic activity, in regions rich in $\mu$-opioid receptors, such as ACC, PFC, Th, basal ganglia and amygdala (Firestone et al., 1996; Schlaepfer et al., 1998; Wagner et al., 2001). Additional areas of change in blood flow responses, both increases and reductions depending on the regions, were also found in areas with relatively low content of $\mu$-opioid receptors, possibly reflecting indirect effects of the opioid agonists activating and inhibiting neuronal systems projecting to these regions. An initial study on the effects of the $\mu$-opioid agonist, fentanyl, on rCBF responses to heat pain did not show clear effects (Adler et al., 1997). Subsequent work using painful cold showed that the enhancements in rCBF elicited by this stimulus were prominently reduced by the $\mu$-opioid agonist in most regions, confirming an inhibitory effect of fentanyl on measures of pain-induced neuronal activity (Casey et al., 2000). Utilizing similar methodology, rCBF responses to a $\mu$-opioid agonist, remifentanil, were compared to that elicited by a placebo (Petrovic et al., 2002a). The two effects overlapped in terms of rCBF increases in dorsal ACC, suggesting that this brain region may be involved in placebo effects. Perhaps more notably, placebo responders showed responses to remifentanil that were more prominent than non-responders. These data suggest that the placebo effect on pain responses may be mediated by inter-individual variations in the ability to activate this neurotransmitter system, as hypothesized by others (Amanzio and Benedetti, 1999).

Direct measures of opioid neurotransmission have been obtained using both non-selective radiotracers for opioid receptors (e.g., diphrenorphine) and $\mu$-opioid receptor selective radiotracers (e.g., carfentanil). Utilizing $\left[{ }^{11} \mathrm{C}\right]$ diphrenorphine, the in vivo availability of opioid receptors was examined in a small group of patients diagnosed with rheumatoid arthritis (Jones et al., 1994), and in six patients diagnosed with trigeminal neuralgia (Jones et al., 1999). Relief of pain was associated with increases in the concentration of opioid receptors binding the radiolabeled tracer in a number of brain regions, which included ACC, IC, PFC, Th, and basal ganglia. The absence of a control group in these studies did not allow the investigators to determine whether the increases in opioid receptor binding after pain relief were comparable to those of individuals free of painful conditions.

Dynamic changes in the activity of endogenous opioid system and $\mu$-opioid receptors have been recently described utilizing a selective $\mu$-opioid radiotracer, $\left[{ }^{11} \mathrm{C}\right]$ carfentanil, and a model of sustained muscular pain in healthy subjects. Reductions in the in vivo availability of $\mu$-opioid receptors, reflecting the activation of this neurotransmitter system, were observed in ACC, PFC, IC, Th, ventral basal ganglia, amygdala and periaqueductal gray. The activation of this neurotransmitter system was also correlated with suppression of sensory and affective qualities of the pain with distinct neuro- 
anatomical localizations (Zubieta et al., 2001). An area uniquely associated with the suppression of pain affect scores, as measured with the McGill Pain Questionnaire pain affect subscale, was the dorsal ACC, which was localized, for this type of scale and sustained pain model, in a region just posterior to a region identified to be involved in acute pain unpleasantness (Rainville et al., 1997; Tolle et al., 1999). Substantial interindividual differences were also observed in both receptor-binding levels and in the magnitude of activation of this neurotransmitter system.

Gender differences in the concentration of $\mu$-opioid receptors had been previously described in human subjects, with women showing higher binding than men in most brain regions. Interestingly, these gender differences were less prominent in the amygdala and thalamus of post-menopausal women, compared to men of the same age, an effect that may be related to the effects of estrogen on $\mu$-opioid receptor concentrations and endogenous opioid neurotransmission (Smith et al., 1998; Zubieta et al., 1999). Higher concentrations of $\mu$-opioid receptors in women would explain the observations of a higher sensitivity to $\mu$-opioid agonists in women in pharmacological challenge studies (Zacny, 2001). Gender differences in the capacity to activate $\mu$-opioid receptor-mediated neurotransmission were subsequently explored using $\left[{ }^{11} \mathrm{C}\right]$ carfentanil and the sustained muscular pain model. Women studied during the early follicular phase of the menstrual cycle, when estradiol and progesterone are lowest, demonstrated lower magnitudes of endogenous opioid system activation than men, at comparable levels of pain intensity. In some brain areas, such as the nucleus accumbens, most women also demonstrated changes in the opposite direction, a deactivation of $\mu$-opioid receptor-mediated neurotransmission, an effect associated with higher ratings of pain during pain challenge (Zubieta et al., 2002). However, even after accounting for gender differences in $\mu$-opioid receptor binding and endogenous opioid system activity, and controlling for menstrual cycle phase in women, substantial inter-individual variations in these measures were still observed.

An additional contribution to the observed variability in $\mu$-opioid receptor binding and the capacity to activate this neurotransmitter system in response to sustained pain was described as a function of a common polymorphism of the catechol- $O$-methyl transferase enzyme (COMT). The substitution of valine (val) by methionine (met) at codon 158 of the COMT gene is associated with a 3-4-fold reduction in the capacity to metabolize catecholamines. These alterations in catecholaminergic neurotransmission resulted in downstream changes in the capacity to activate $\mu$-opioid system responses to sustained pain, with lowest function in met/met, intermediate in met/val, and highest in vallval subjects (Zubieta et al., 2003). Aside from the impor- tance of this work in understanding inter-individual variations in the regulation of pain, it also describes a point of interaction between neurotransmitter systems, such as the noradrenergic and dopaminergic, involved in responses to stress, salient stimuli and reward, with pain regulatory mechanisms.

Reductions in presynaptic dopaminergic function in the basal ganglia have been reported in idiopathic burning mouth syndrome, as measured by the dopamine precursor $\left[{ }^{18} \mathrm{~F}\right]$ fluorodopa (FDOPA) and PET (Jaaskelainen et al., 2001). These data seem consistent with findings by the same group of increases in dopamine D2, but not $\mathrm{D} 1$, receptor binding in the same brain regions of these patients (Hagelberg et al., 2003). The increases in D2 receptor binding were interpreted as reflecting a reduction in dopamine activity in the basal ganglia, in agreement with the FDOPA findings initially reported. The possible involvement of dopamine D2 receptors in pain regulatory mechanisms was also supported by findings that the concentration of $\mathrm{D} 2$ receptors in the basal ganglia of healthy controls was correlated with the tolerance to a tonic pain challenge (Hagelberg et al., 2002). Reciprocal interactions between catecholaminergic and opioid mechanisms are therefore emerging as important factors in the regulation of responses to pain and their interaction with other environmental and genetic influences (Hagelberg et al., 2002; Zubieta et al., 2003).

\subsection{Brain activity in clinical pain states}

The advent of non-invasive brain imaging techniques afforded the new opportunity of examining brain processes in clinical pain conditions, and now significant progress has been made in this direction. The earliest hemodynamic studies attempted to identify brain activity that would differentiate clinical pain states from acute pain (Cesaro et al., 1991; Di Piero et al., 1991). Since these early reports, many clinical pain conditions have been examined (eTable 5).

Given the success of identifying a unique, fairly reproducible, brain activity pattern for painful stimuli in normal subjects (see above), one early approach in the attempt to study clinical pain states was the application of the same method to various pain patient populations. In a series of studies, brain activity to thermal stimuli was reported to be abnormal in rheumatoid arthritis, in patients with atypical facial pain, and patients with post-tooth extraction pain (Derbyshire et al., 1999, 1994; Jones and Derbyshire, 1997). These studies generally showed decreased activity in various components of the brain regions activated in normal subjects for thermal pain. Thermal stimuli were usually applied to the hand, a site remote from the body part where the clinical pain was felt, and it was usually not accompanied with psychophysical tests to measure differences in thermal pain thresholds at the injury site 
or at the test site. Thus, these results have remained mostly un-interpretable mainly because one is not sure whether the changes reflect properties fundamental to the condition or if they are a reflection of non-specific effects such as reduced attention to the stimulus. A recent comprehensive study, where a large group of low back pain patients was compared to matched normal controls, failed to demonstrate significant changes in brain responses to thermal stimuli applied to the hand between the groups (Derbyshire et al., 2002), lending support to the suspicion that the earlier reports were based on small non-specific differences. Another recent study demonstrated that thermal stimulation in complex regional pain syndrome (CRPS) patients gives rise to activity that closely matches that observed in normal subjects. However, this pattern changes dramatically when the ongoing pain of CRPS is isolated, by comparing brain activity before and after sympathetic blocks that reduce the ongoing CRPS pain but do not change the thermal stimulus pain (Apkarian et al., 2001). Thus, there is no compelling evidence that examining brain responses to experimental painful stimuli can predict the pattern of brain responses in chronic clinical pain states.

A direct approach to studying clinical pain states is to provoke the condition and examine underlying brain activity (eTable 5). This is readily doable by drugs in headaches and in cardiac pain. As a result there are now high quality studies in both fields, and in both fields the results force the conclusion that the brain plays an active, if not a central, role in these conditions. There is also now good evidence that migraine with aura is accompanied with decreased blood flow and decreased activity in the occipital cortex. Gastrointestinal disorders can be studied directly by distending parts of the organ and examining related brain activity. A number of groups have adopted this strategy with varying success. Again the results have prompted a debate regarding the importance of central activity in irritable bowel syndrome (IBS). Given that IBS has a strong predominance in women and serotonin (5-HT) is suspected to be part of its pathophysiology, a recent study examined 5-HT binding in the brain of patients with IBS and showed 5-HT synthesis was greater in female IBS patients, thus linking brain neuromodulators to IBS (Nakai et al., 2003). Fibromyalgia and chronic neuropathic pain conditions have posed a tougher challenge, mainly because neither the experimenter nor the patient has the ability to systematically manipulate the properties of the condition. An elegant approach was demonstrated recently for studying fibromyalgia (Gracely et al., 2002), where the authors equated stimulus intensities and perception intensities between patients and normal subjects by rigorous psychophysical measurements, and thus were able to pinpoint brain abnormalities after equating perception.
A number of groups have used allodynia induced by intradermal capsaicin injection as a model for studying central activity related to chronic pain (eTable 5). One study (Lorenz et al., 2002) examined thermal allodynia by equating stimulus and perception during allodynia to the normal state, a similar design as the fibromyalgia study (Gracely et al., 2002), and demonstrated that after equating for perceptions the brain activity for thermal pain during allodynia is different from that observed for the equivalent stimulus in normal skin.

Another approach for documenting the impact of chronic pain on the brain is the examination of brain chemistry using non-invasive ${ }^{1} \mathrm{H}$ MR spectroscopy (MRS, eTable 5). The advantage of the method is the stability of the signals analyzed since chemicals examined by this technique are independent of the cognitive state of the person at scan time. Thus, when changes in chemical concentrations are uncovered they are presumed to reflect long-term plasticity. Concentrations relative to an internal standard have been used to probe brain chemistry of chronic back pain. These studies show that brain chemistry is abnormal mainly in PFC. Moreover, different subregions within this cortex differentially correlate with various characteristics of the chronic pain, such as sensory and affective dimensions, anxiety and depression. These studies also show that interrelationships of chemicals across brain areas are disrupted in the patients as compared to normal subjects. Thalamic chemistry abnormalities have also been reported in patients with central, spinal cord injury, pain. These chemical changes are compelling evidence that the presence of chronic pain has an underlying brain chemical basis, may be reflecting the long-term plasticity that one suspects to accompany chronic pain.

We tested whether brain activity in clinical conditions shows the same or a different pattern as brain activity evoked by experimental pain in normal subjects, by comparing incidences of significant activation of several brain areas across these two conditions (Table 2; derived from eTables 1 and 5). The included clinical studies are those where the authors attempted to isolate brain activity specifically related to the condition. The comparison shows that chronic clinical pain conditions more frequently involve PFC (81\% in clinical conditions vs. $55 \%$ in normal subjects, Table 3), while in normal subjects perception of experimental pain more frequently involves S1, S2, Th, and ACC (average incidence across the five areas is $42 \%$ in clinical conditions vs. $82 \%$ in normal subjects, Table 3 ). Consistent with this pattern is the observation that in normal subjects ACC activity is correlated with pain intensity or perceived pain intensity due to rectal distension, and this correlation disappears in irritable bowel syndrome patients (Silverman et al., 1997; Mertz et al., 2000), and in heat allodynia (Lorenz et al., 2002). 
In contrast to experimentally induced pain in normal subjects, chronic clinical pain conditions are often associated with decreased baseline activity or decreased stimulus related activity in the thalamus (six studies in eTable 5). A SPECT blood flow study (Fukumoto et al., 1999) has shown a strong relationship between time of onset of CRPS symptoms and thalamic activity. The ratio between contralateral to ipsilateral thalamic perfusion was larger than 1.0, indicating hyperperfusion, for patients with symptoms for only 3-7 months, and smaller than 1.0, indicating hypoperfusion, for patients with longer-term symptoms (24-36 months), with a correlation coefficient of 0.97 (normal subjects had a thalamic perfusion ratio of about 1.0). These data strongly imply that the thalamus undergoes adaptive changes in the course of CRPS. Thus, we can assert that brain activity for pain in chronic clinical conditions is different from brain activity for acute painful stimuli in normal subjects. We add the caution that this does not imply that all clinical pain conditions have a homogeneous underlying brain activity pattern. On the contrary, most likely the patterns involving different clinical conditions are unique but with the current available data we cannot test this at a meta-analysis level.

EEG signals can show impaired function of the nociceptive pathways in a variety of disorders (Bromm et al., 1991; Treede et al., 1991; Kakigi et al., 1992; Kanda et al., 1996; Cruccu et al., 1999; Truini et al., 2003). Most of these studies use laser-evoked potentials, which are reliably detected in healthy subjects (Spiegel et al., 2000; Devos et al., 2000). This approach, however, is less sensitive in detecting clinical pain conditions (Gibson et al., 1994; Lorenz et al., 1996; Garcia-Larrea et al., 2002).

Recent EEG and MEG studies have advanced our understanding of phantom limb pain. Animal experiments had demonstrated that the receptive fields of neurons in the primary somatosensory cortex move to adjacent skin areas when nerve lesions or amputations interrupted their original input. This reorganization of receptive fields of deafferented neurons was originally thought to be a protective mechanism against the development of phantom sensations. When this prediction was tested in human amputees, however, the opposite relationship was observed: the amount of phantom limb pain was positively (not negatively) correlated with the amount of cortical reorganization (Flor et al., 1995; Knecht et al., 1998; Montoya et al., 1998; Grusser et al., 2001; Karl et al., 2001). Although the correlation of cortical reorganization and phantom limb pain was also valid during pain relief by adequate treatment, the relationship between the two phenomena is unclear, because the reorganization is observed for tactile (not nociceptive) inputs to the primary somatosensory cortex. Thus, these findings do not represent a cortical pain mechanism, but may be relevant for our general under- standing of the somatosensory system. A recent PET study may be more salient to identifying brain regions involved in phantom limb pain: by hypnotic suggestions of painful vs. painless phantom limb positions, the authors were able to show a brain activity pattern similar to other pain conditions (Willoch et al., 2000).

\section{Comments}

The brain imaging studies reviewed here indicate the cortical and sub-cortical substrate that underlies pain perception. Instead of locating a singular "pain center" in the brain, neuroimaging studies identify a network of somatosensory (S1, S2, IC), limbic (IC, ACC) and associative (PFC) structures receiving parallel inputs from multiple nociceptive pathways (Fig. 1). In contrast to touch, pain invokes an early activation of S2 and IC that may play a prominent role in sensory-discriminative functions of pain. The strong affective-motivational character of pain is exemplified by the participation of regions of the cingulate gyrus. The intensity and affective quality of perceived pain is the net result of the interaction between ascending nociceptive inputs and antinociceptive controls. Dysregulations in the function of these networks may underlie vulnerability factors for the development of chronic pain and comorbid conditions.

The review also highlights the types of information that has been garnered regarding this pain network by the different imaging modalities. The meta-analysis indicates that the members of the pain network are best identified by hemodynamic imaging methods, while the temporal sequence and time delays to activating different cortical regions are best studied with EEG and MEG methods. Brain regions involved in modulating pain perception seem identified best with studies involving neurotransmitter and neuroreceptor changes, although psychological modulation of pain is also being examined with fMRI, PET, and EEG/MEG studies. There seems to be good evidence for somatotopic organization for pain representation in some brain areas, with divergent views when studied with hemodynamic methods or with EEG or MEG methods.

Our meta-analysis shows that experimental pain in normal subjects and chronic clinical pain conditions have distinct but overlapping brain activation patterns. Studies in normal subjects tend to emphasize transmission through the spinothalamic pathway, which transmits afferent nociceptive information through Th to S1, S2, IC and ACC. The meta-analysis indicates that the primary brain areas accessed through this pathway decrease in their activation incidence in chronic clinical pain. In contrast, the PFC activity seems to increase in incidence in clinical pain conditions. Since pathways outside of the spinothalamic tract, such as spinoparabrachial, 
spinohypothalamic and spinoreticular projections, may activate PFC, we propose that nociceptive information transmission through those pathways may become more important in chronic clinical pain conditions. A similar conclusion was arrived at by Hunt and Mantyh (2001) based on studying peripheral and spinal cord changes that accompany neuropathic pain-like behavior in rodents. It should be emphasized that the PFC is a heterogeneous brain area, where different subdivisions are thought to play specific roles in various cognitive, emotional and memory functions. In this review, we have not distinguished between the different components of PFC, although various studies do show distinct portions of PFC activated. We presume that different clinical pain conditions may in fact involve various components of PFC, but these await future studies. The preferential activation of PFC in clinical conditions suggests the simple hypothesis that chronic pain states have stronger cognitive, emotional, and introspective components than acute pain conditions. Decreased incidence of activity across ACC, S1, S2, IC, and Th in chronic pain conditions as compared to brain activity for pain in normal subjects has been observed in an earlier metaanalysis (Derbyshire, 1999) (decreased incidence of ACC and Th in chronic pain in contrast to pain in normal subjects was also noted by Peyron et al., 2000). On the other hand, the increase in incidence in PFC in clinical conditions was not observed. This resulted in the author stating that his analysis reveals 'a generally reduced response to noxious stimulation in patients with concomitant clinical pain' and concluding that 'the most parsimonious explanation being increased response variability in patients' (Derbyshire, 1999). Our analysis, instead, suggests that chronic pain conditions may be a reflection of decreased sensory processing and enhanced emotional/cognitive processing. The clinical pain states studied were heterogeneous, including cancer pain, headache, visceral pain and neuropathic pain. Other than being chronic and of high personal salience for the afflicted patient, these conditions probably have little in common that may explain the concordant activation of PFC.

Craig et al. $(1994,1996)$ proposed that central pain may be a consequence of disinhibition within the spinothalamic pathway. Given that central pain has similar characteristics to the more general chronic neuropathic pain condition, the present results can be used to test Craig's hypothesis. The decreased incidence of activity in ACC and Th, coupled with decreased coding for perceived pain in ACC, as well as increased incidence of activity in PFC in chronic pain conditions all contradict Craig's hypothesis. Thus, we can state that his hypothesis does not apply to chronic pain in general. It is possible however that the common assumption that central pain and neuropathic pain are similar entities may simply be false, keeping Craig's hypothesis unchallenged in the specific example where it was formulated, see Casey (2004) for a more thorough discussion of central pain, new relevant data, and alternative hypotheses. The format and organization of this review require commenting. We attempted to review the literature in the field using a systematic approach. To this end, we used eTables to present the literature and the salient results used in our analyses. To perform quantitative meta-analysis, we restricted the brain regions and the decision as to the presence of activity in a given region to very simple binary criteria. The results from these decisions are also included in the eTables. By simplifying the decisions regarding activity in a given brain region, we were able to construct testable hypotheses as to efficacy of imaging brain activity with different methods and for pain representation in normal subjects in comparison to clinical conditions. Because of the heterogeneity of the included studies, our quantitative findings are less stringent than e.g. systematic reviews of post-operative pain treatment, and hence should be interpreted with caution. Still, a large portion of this review remains descriptive due to the limited number of studies and due to our bias that good individual studies usually provide more reliable information than more inclusive meta-analyses of everything published in the field. The same limitations apply to other systematic reviews in the field (Derbyshire, 1999, 2003; Peyron et al., 2000).

Overall, this review highlights the important progress that has taken place over the last decade in our understanding of the role of the brain in pain states. As the review indicates this field has matured, in pace with advancements in non-invasive brain imaging methodologies, and has made multiple original contributions to brain mechanisms of pain. We fully expect that the next generation brain imaging studies of pain will impact on clinical practice and thus contribute to decreasing pain in society.

\section{References}

Anon. Brain mapping the methods. Amsterdam: Academic Press; 2002.

Adler LJ, Gyulai FE, Diehl DJ, Mintun MA, Winter PM, Firestone LL. Regional brain activity changes associated with fentanyl analgesia elucidated by positron emission tomography. Anesth Analg 1997;84:120-6.

Amanzio M, Benedetti F. Neuropharmacological dissection of placebo analgesia: expectation-activated opioid systems versus conditioning-activated specific subsystems. J Neurosci 1999;19: 484-94.

Andersson J. Regional cerebral blood flow and oxygen metabolism. Cephalalgia 1998;18:2-4.

Andersson JL, Lilja A, Hartvig P, Langstrom B, Gordh T, Handwerker $\mathrm{H}$, et al. Somatotopic organization along the central sulcus, for pain localization in humans, as revealed by positron emission tomography. Exp Brain Res 1997;117:192-9.

Apkarian AV, Darbar A, Krauss BR, Gelnar PA, Szeverenyi NM. Differentiating cortical areas related to pain perception from 
stimulus identification: temporal analysis of fMRI activity. J Neurophysiol 1999;81:2956-63.

Apkarian AV, Gelnar PA, Krauss BR, Szeverenyi NM. Cortical responses to thermal pain depend on stimulus size: a functional MRI study. J Neurophysiol 2000;83:3113-22.

Apkarian AV, Shi T. Squirrel monkey lateral thalamus. I. Somatic nociresponsive neurons and their relation to spinothalamic terminals. J Neurosci 1994;14:6779-95.

Apkarian AV, Stea RA, Manglos SH, Szeverenyi NM, King RB, Thomas FD. Persistent pain inhibits contralateral somatosensory cortical activity in humans. Neurosci Lett 1992;140:141-7.

Apkarian AV, Thomas PS, Krauss BR, Szeverenyi NM. Prefrontal cortical hyperactivity in patients with sympathetically mediated chronic pain. Neurosci Lett 2001;311:193-7.

Arendt-Nielsen L. Second pain event related potentials to argon laser stimuli: recording and quantification. J Neurol Neurosurg Psychiatry 1990;53:405-10.

Arendt-Nielsen L, Yamasaki H, Nielsen J, Naka D, Kakigi R. Magnetoencephalographic responses to painful impact stimulation. Brain Res 1999;839:203-8.

Arendt-Nielsen L, Zachariae R, Bjerring P. Quantitative evaluation of hypnotically suggested hyperaesthesia and analgesia by painful laser stimulation. Pain 1990;42:243-51.

Aziz Q, Andersson JL, Valind S, Sundin A, Hamdy S, Jones AK, et al. Identification of human brain loci processing esophageal sensation using positron emission tomography. Gastroenterology 1997;113:50-9.

Baciu MV, Bonaz BL, Papillon E, Bost RA, Le Bas JF, Fournet J, et al. Central processing of rectal pain: a functional MR imaging study. AJNR Am J Neuroradiol 1999;20:1920-4.

Backonja M, Howland EW, Wang J, Smith J, Salinsky M, Cleeland CS. Tonic changes in alpha power during immersion of the hand in cold water. Electroencephalogr Clin Neurophysiol 1991;79: 192-203.

Bantick SJ, Wise RG, Ploghaus A, Clare S, Smith SM, Tracey I. Imaging how attention modulates pain in humans using functional MRI. Brain 2002;125:310-9.

Baron R, Baron Y, Disbrow E, Roberts TP. Brain processing of capsaicin-induced secondary hyperalgesia: a functional MRI study. Neurology 1999;53:548-57.

Becerra L, Breiter HC, Wise R, Gonzalez RG, Borsook D. Reward circuitry activation by noxious thermal stimuli. Neuron 2001;32:927-46.

Becerra LR, Breiter HC, Stojanovic M, Fishman S, Edwards A, Comite AR, et al. Human brain activation under controlled thermal stimulation and habituation to noxious heat: an fMRI study. Magn Reson Med 1999;41:1044-57.

Bentley DE, Youell PD, Jones AK. Anatomical localization and intrasubject reproducibility of laser evoked potential source in cingulate cortex, using a realistic head model. Clin Neurophysiol 2002;113:1351-6.

Berman SM, Chang L, Suyenobu B, Derbyshire SW, Stains J, Fitzgerald L, et al. Condition-specific deactivation of brain regions by 5 -HT3 receptor antagonist Alosetron. Gastroenterology 2002;123:969-77.

Bernstein CN, Frankenstein UN, Rawsthorne P, Pitz M, Summers R, McIntyre MC. Cortical mapping of visceral pain in patients with GI disorders using functional magnetic resonance imaging. Am J Gastroenterol 2002;97:319-27.

Beydoun A, Morrow TJ, Shen JF, Casey KL. Variability of laserevoked potentials: attention, arousal and lateralized differences. Electroencephalogr Clin Neurophysiol 1993;88:173-81.

Bingel U, Quante M, Knab R, Bromm B, Weiller C, Buchel C. Subcortical structures involved in pain processing: evidence from single-trial fMRI. Pain 2002;99:313-21.

Bingel U, Quante M, Knab R, Bromm B, Weiller C, Buchel C. Single trial fMRI reveals significant contralateral bias in responses to laser pain within thalamus and somatosensory cortices. Neuroimage 2003; 18:740-8.

Binkofski F, Schnitzler A, Enck P, Frieling T, Posse S, Seitz RJ, et al. Somatic and limbic cortex activation in esophageal distention: a functional magnetic resonance imaging study. Ann Neurol 1998;44:811-5.

Bonaz B, Baciu M, Papillon E, Bost R, Gueddah N, Le Bas JF, et al. Central processing of rectal pain in patients with irritable bowel syndrome: an fMRI study. Am J Gastroenterol 2002;97: 654-61.

Bragard D, Chen AC, Plaghki L. Direct isolation of ultra-late (C-fibre) evoked brain potentials by $\mathrm{CO}_{2}$ laser stimulation of tiny cutaneous surface areas in man. Neurosci Lett 1996;209:81-4.

Bromm B, Chen AC. Brain electrical source analysis of laser evoked potentials in response to painful trigeminal nerve stimulation. Electroencephalogr Clin Neurophysiol 1995;95:14-26.

Bromm B, Frieling A, Lankers J. Laser-evoked brain potentials in patients with dissociated loss of pain and temperature sensibility. Electroencephalogr Clin Neurophysiol 1991;80:284-91.

Bromm B, Treede RD. $\mathrm{CO}_{2}$ laser radiant heat pulses activate $\mathrm{C}$ nociceptors in man. Pflugers Arch 1983;399:155-6.

Brooks JC, Nurmikko TJ, Bimson WE, Singh KD, Roberts N. fMRI of thermal pain: effects of stimulus laterality and attention. Neuroimage 2002;15:293-301.

Buchel C, Bornhovd K, Quante M, Glauche V, Bromm B, Weiller C. Dissociable neural responses related to pain intensity, stimulus intensity, and stimulus awareness within the anterior cingulate cortex: a parametric single-trial laser functional magnetic resonance imaging study. J Neurosci 2002;22:970-6.

Bushnell MC, Duncan GH, Hofbauer RK, Ha B, Chen JI, Carrier B. Pain perception: is there a role for primary somatosensory cortex? Proc Natl Acad Sci USA 1999;96:7705-9.

Cao Y, Welch KMA, Aurora S, Vikingstad EM. Functional MRIBOLD of visually triggered headache in patients with migraine. Arch Neurol 1999;56:548-54.

Casey KL. Central pain: distributed effects of focal lesions. Pain 2004;108:205-6.

Casey KL, Minoshima S, Berger KL, Koeppe RA, Morrow TJ, Frey KA. Positron emission tomographic analysis of cerebral structures activated specifically by repetitive noxious heat stimuli. J Neurophysiol 1994;71:802-7.

Casey KL, Minoshima S, Morrow TJ, Koeppe RA. Comparison of human cerebral activation pattern during cutaneous warmth, heat pain, and deep cold pain. J Neurophysiol 1996;76:571-81.

Casey KL, Morrow TJ, Lorenz J, Minoshima S. Temporal and spatial dynamics of human forebrain activity during heat pain: analysis by positron emission tomography. J Neurophysiol 2001;85:951-9.

Casey KL, Svensson P, Morrow TJ, Raz J, Jone C, Minoshima S. Selective opiate modulation of nociceptive processing in the human brain. J Neurophysiol 2000;84:525-33.

Cesaro P, Mann MW, Moretti JL, Defer G, Roualdes B, Nguyen JP, et al. Central pain and thalamic hyperactivity: a single photon emission computerized tomographic study. Pain 1991;47: 329-36.

Chang PF, Arendt-Nielsen L, Chen AC. Differential cerebral responses to aversive auditory arousal versus muscle pain: specific EEG patterns are associated with human pain processing. Exp Brain Res 2002;147:387-93.

Chen AC, Rappelsberger P, Filz O. Topology of EEG coherence changes may reflect differential neural network activation in cold and pain perception. Brain Topogr 1998;11:125-32.

Chen JI, Ha B, Bushnell MC, Pike B, Duncan GH. Differentiating noxious- and innocuous-related activation of human somatosensory cortices using temporal analysis of fMRI. J Neurophysiol 2002;88:464-74.

Coghill RC, Gilron I, Iadarola MJ. Hemispheric lateralization of somatosensory processing. J Neurophysiol 2001;85:2602-12. 
Coghill RC, Sang CN, Berman KF, Bennett GJ, Iadarola MJ. Global cerebral blood flow decreases during pain. J Cereb Blood Flow Metab 1998;18:141-7.

Coghill RC, Sang CN, Maisog JM, Iadarola MJ. Pain intensity processing within the human brain: a bilateral, distributed mechanism. J Neurophysiol 1999;82:1934 43.

Craig AD. How do you feel? Interoception: the sense of the physiological condition of the body. Nat Rev Neurosci 2002;3:655-66.

Craig AD, Bushnell MC, Zhang ET, Blomqvist A. A thalamic nucleus specific for pain and temperature sensation. Nature 1994;372:770-3.

Craig AD, Reiman EM, Evans A, Bushnell MC. Functional imaging of an illusion of pain. Nature 1996;384:258-60.

Crawford HJ, Gur RC, Skolnick B, Gur RE, Benson DM. Effects of hypnosis on regional cerebral blood flow during ischemic pain with and without suggested hypnotic analgesia. Int J Psychophysiol 1993;15:181-95.

Creac'h C, Henry P, Caille JM, Allard M. Functional MR imaging analysis of pain-related brain activation after acute mechanical stimulation. AJNR Am J Neuroradiol 2000;21:1402-6.

Cruccu G, Romaniello A, Amantini A, Lombardi M, Innocenti P, Manfredi M. Assessment of trigeminal small-fiber function: brain and reflex responses evoked by $\mathrm{CO}_{2}$-laser stimulation. Muscle Nerve 1999;22:508-16.

Cutrer FM, Sorensen AG, Weisskoff RM, Ostergaard L, del Rio MS, Lee EJ, et al. Perfusion-weighted imaging defects during spontaneous migrainous aura. Ann Neurol 1998;43:25-31.

DaSilva AF, Becerra L, Makris N, Strassman AM, Gonzalez RG, Geatrakis N, et al. Somatotopic activation in the human trigeminal pain pathway. J Neurosci 2002;22:8183-92.

Davis KD. Neurophysiological and anatomical considerations in functional imaging of pain. Pain 2003;105:1-3.

Davis KD, Kwan CL, Crawley AP, Mikulis DJ. Functional MRI study of thalamic and cortical activations evoked by cutaneous heat, cold, and tactile stimuli. J Neurophysiol 1998;80: 1533-46.

Davis KD, Pope GE, Crawley AP, Mikulis DJ. Neural correlates of prickle sensation: a percept-related fMRI study. Nat Neurosci 2002;5:1121-2.

Davis KD, Taub E, Duffner F, Lozano AM, Tasker RR, Houle S, et al. Activation of the anterior cingulate cortex by thalamic stimulation in patients with chronic pain: a positron emission tomography study. J Neurosurg 2000;92:64-9.

Davis KD, Taylor SJ, Crawley AP, Wood ML, Mikulis DJ. Functional MRI of pain- and attention-related activations in the human cingulate cortex. J Neurophysiol 1997;77:3370-80.

Davis KD, Wood ML, Crawley AP, Mikulis DJ. fMRI of human somatosensory and cingulate cortex during painful electrical nerve stimulation. Neuroreport 1995;7:321-5.

Del Gratta C, Della PS, Ferretti A, Franciotti R, Pizzella V, Tartaro A, et al. Topographic organization of the human primary and secondary somatosensory cortices: comparison of fMRI and MEG findings. Neuroimage 2002;17:1373-83.

Del Gratta C, Della PS, Tartaro A, Ferretti A, Torquati K, Bonomo $\mathrm{L}$, et al. Topographic organization of the human primary and secondary somatosensory areas: an fMRI study. Neuroreport 2000;11:2035-43.

Derbyshire SW. Meta-analysis of thirty-four independent samples studied using PET reveals a significantly attenuated central response to noxious stimulation in clinical pain patients. Curr Rev Pain 1999;3:265-80.

Derbyshire SW. A systematic review of neuroimaging data during visceral stimulation. Am J Gastroenterol 2003;98:12-20.

Derbyshire SW, Jones AK. Cerebral responses to a continual tonic pain stimulus measured using positron emission tomography. Pain 1998;76:127-35.
Derbyshire SW, Jones AK, Collins M, Feinmann C, Harris M. Cerebral responses to pain in patients suffering acute post-dental extraction pain measured by positron emission tomography (PET). Eur J Pain 1999;3:103-13.

Derbyshire SW, Jones AK, Creed F, Starz T, Meltzer CC, Townsend DW, et al. Cerebral responses to noxious thermal stimulation in chronic low back pain patients and normal controls. Neuroimage 2002;16:158-68.

Derbyshire SW, Jones AK, Devani P, Friston KJ, Feinmann C, Harris $\mathrm{M}$, et al. Cerebral responses to pain in patients with atypical facial pain measured by positron emission tomography. J Neurol Neurosurg Psychiatry 1994;57:1166-72.

Derbyshire SW, Jones AK, Gyulai F, Clark S, Townsend D, Firestone LL. Pain processing during three levels of noxious stimulation produces differential patterns of central activity. Pain 1997;73:431-45.

Derbyshire SW, Vogt BA, Jones AK. Pain and stroop interference tasks activate separate processing modules in anterior cingulate cortex. Exp Brain Res 1998;118:52-60.

Devos D, Creac'h C, Laureau E, Bourriez JL, Guieu JD. Thulium laser evoked potentials. Normative values for the arms and legs. Neurophysiol Clin 2000;30:313-22.

Di Piero V, Jones AK, Iannotti F, Powell M, Perani D, Lenzi GL, et al. Chronic pain: a PET study of the central effects of percutaneous high cervical cordotomy. Pain 1991;46:9-12.

Dillmann J, Miltner WH, Weiss T. The influence of semantic priming on event-related potentials to painful laser-heat stimuli in humans. Neurosci Lett 2000;284:53-6.

Disbrow E, Buonocore M, Antognini J, Carstens E, Rowley HA. Somatosensory cortex: a comparison of the response to noxious thermal, mechanical, and electrical stimuli using functional magnetic resonance imaging. Hum Brain Mapp 1998;6:150-9.

Disbrow E, Roberts T, Krubitzer L. Somatotopic organization of cortical fields in the lateral sulcus of Homo sapiens: evidence for SII and PV. J Comp Neurol 2000;418:1-21.

Dowman R. Attentional set effects on spinal and supraspinal responses to pain. Psychophysiology 2001;38:451-64.

Dowman R, Schell S. Evidence that the anterior cingulate and supplementary somatosensory cortices generate the pain-related negative difference potential. Clin Neurophysiol 1999;110: 2117-26.

Druschky K, Lang E, Hummel C, Kaltenhauser M, Kohlloffel LU, Neundorfer B, et al. Pain-related somatosensory evoked magnetic fields induced by controlled ballistic mechanical impacts. J Clin Neurophysiol 2000;17:613-22.

Duncan GH, Kupers RC, Marchand S, Villemure JG, Gybels JM, Bushnell MC. Stimulation of human thalamus for pain relief: possible modulatory circuits revealed by positron emission tomography. J Neurophysiol 1998;80:3326-30.

Fabri M, Polonara G, Quattrini A, Salvolini U. Mechanical noxious stimuli cause bilateral activation of parietal operculum in callosotomized subjects. Cereb Cortex 2002;12:446-51.

Faymonville ME, Laureys S, Degueldre C, DelFiore G, Luxen A, Franck G, et al. Neural mechanisms of antinociceptive effects of hypnosis. Anesthesiology 2000;92:1257-67.

Ferracuti S, Seri S, Mattia D, Cruccu G. Quantitative EEG modifications during the Cold Water Pressor Test: hemispheric and hand differences. Int J Psychophysiol 1994;17:261-8.

Firestone LL, Gyulai F, Mintun M, Adler LJ, Urso K, Winter PM. Human brain activity response to fentanyl imaged by positron emission tomography. Anesth Analg 1996;82:1247-51.

Flor H, Elbert T, Knecht S, Wienbruch C, Pantev C, Birbaumer N, et al. Phantom-limb pain as a perceptual correlate of cortical reorganization following arm amputation. Nature 1995;375:482-4.

Frankenstein UN, Richter W, McIntyre MC, Remy F. Distraction modulates anterior cingulate gyrus activations during the cold pressor test. Neuroimage 2001;14:827-36. 
Friederich M, Trippe RH, Ozcan M, Weiss T, Hecht H, Miltner WH. Laser-evoked potentials to noxious stimulation during hypnotic analgesia and distraction of attention suggest different brain mechanisms of pain control. Psychophysiology 2001;38: $768-76$.

Frot M, Mauguiere F. Dual representation of pain in the operculoinsular cortex in humans. Brain 2003;126:438-50.

Frot M, Rambaud L, Guenot M, Mauguiere F. Intracortical recordings of early pain-related $\mathrm{CO}_{2}$-laser evoked potentials in the human second somatosensory (SII) area. Clin Neurophysiol 1999;110:133-45.

Fukumoto M, Ushida T, Zinchuk VS, Yamamoto H, Yoshida S. Contralateral thalamic perfusion in patients with reflex sympathetic dystrophy syndrome. Lancet 1999;354:1790-1.

Fulbright RK, Troche CJ, Skudlarski P, Gore JC, Wexler BE. Functional MR imaging of regional brain activation associated with the affective experience of pain. AJR Am J Roentgenol 2001;177:1205-10.

Garcia-Larrea L, Convers P, Magnin M, Andre-Obadia N, Peyron R, Laurent B, et al. Laser-evoked potential abnormalities in central pain patients: the influence of spontaneous and provoked pain. Brain 2002;125:2766-81.

Garcia-Larrea L, Peyron R, Laurent B, Mauguiere F. Association and dissociation between laser-evoked potentials and pain perception. Neuroreport 1997;8:3785-9.

Gelnar PA, Krauss BR, Sheehe PR, Szeverenyi NM, Apkarian AV. A comparative fMRI study of cortical representations for thermal painful, vibrotactile, and motor performance tasks. Neuroimage 1999;10:460-82.

Gibson SJ, Littlejohn GO, Gorman MM, Helme RD, Granges G. Altered heat pain thresholds and cerebral event-related potentials following painful $\mathrm{CO}_{2}$ laser stimulation in subjects with fibromyalgia syndrome. Pain 1994;58:185-93.

Gracely RH, Petzke F, Wolf JM, Clauw DJ. Functional magnetic resonance imaging evidence of augmented pain processing in fibromyalgia. Arthritis Rheum 2002;46:1333-43.

Grachev ID, Fredickson BE, Apkarian AV. Dissociating anxiety from pain: mapping the neuronal marker $N$-acetyl aspartate to perception distinguishes closely interrelated characteristics of chronic pain. Mol Psychiatry 2001;6:256-8.

Grachev ID, Fredrickson BE, Apkarian AV. Abnormal brain chemistry in chronic back pain: an in vivo proton magnetic resonance spectroscopy study. Pain 2000;89:7-18.

Grachev ID, Fredrickson BE, Apkarian AV. Brain chemistry reflects dual states of pain and anxiety in chronic low back pain. J Neural Transm 2002;109:1309-34.

Grachev ID, Ramachandran TS, Thomas PS, Szeverenyi NM, Fredrickson BE. Association between dorsolateral prefrontal $\mathrm{N}$ acetyl aspartate and depression in chronic back pain: an in vivo proton magnetic resonance spectroscopy study. J Neural Transm 2003;110:287-312.

Grusser SM, Winter C, Muhlnickel W, Denke C, Karl A, Villringer K, et al. The relationship of perceptual phenomena and cortical reorganization in upper extremity amputees. Neuroscience 2001;102:263-72.

Hagelberg N, Forssell H, Rinne JO, Scheinin H, Taiminen T, Aalto S, et al. Striatal dopamine D1 and D2 receptors in burning mouth syndrome. Pain 2003;101:149-54.

Hagelberg N, Kajander JK, Nagren K, Hinkka S, Hietala J, Scheinin $\mathrm{H}$. Mu-receptor agonism with alfentanil increases striatal dopamine D2 receptor binding in man. Synapse 2002;45:25-30.

Hari R, Kaukoranta E, Reinikainen K, Huopaniemie T, Mauno J. Neuromagnetic localization of cortical activity evoked by painful dental stimulation in man. Neurosci Lett 1983;42:77-82.

Hari R, Portin K, Kettenmann B, Jousmaki V, Kobal G. Righthemisphere preponderance of responses to painful $\mathrm{CO}_{2}$ stimulation of the human nasal mucosa. Pain 1997;72:145-51.
Helmchen C, Mohr C, Erdmann C, Petersen D, Nitschke MF. Differential cerebellar activation related to perceived pain intensity during noxious thermal stimulation in humans: a functional magnetic resonance imaging study. Neurosci Lett 2003;335:202-6.

Hofbauer RK, Rainville P, Duncan GH, Bushnell MC. Cortical representation of the sensory dimension of pain. J Neurophysiol 2001;86:402-11.

Hoshi Y. Functional near-infrared optical imaging: utility and limitations in human brain mapping. Psychophysiology 2003;40:511-20.

Hoshiyama M, Kakigi R. After-effect of transcutaneous electrical nerve stimulation (TENS) on pain-related evoked potentials and magnetic fields in normal subjects. Clin Neurophysiol 2000;111:717-24.

Hsieh JC, Belfrage M, Stoneelander S, Hansson P, Ingvar M. Central representation of chronic ongoing neuropathic pain studied positron emission tomography. Pain 1995;63:225-36.

Hsieh JC, Hannerz J, Ingvar M. Right-lateralised central processing for pain of nitroglycerin-induced cluster headache. Pain 1996;67:59-68.

Hsieh JC, Meyerson BA, Ingvar M. PET study on central processing of pain in trigeminal neuropathy. Eur J Pain 1999;3:51-65.

Hsieh JC, Stone-Elander S, Ingvar M. Anticipatory coping of pain expressed in the human anterior cingulate cortex: a positron emission tomography study. Neurosci Lett 1999;262:61-4.

Hunt SP, Mantyh PW. The molecular dynamics of pain control. Nat Rev Neurosci 2001;2:83-91.

Iadarola MJ, Berman KF, Zeffiro TA, Byas-Smith MG, Gracely RH, Max MB, et al. Neural activation during acute capsaicin-evoked pain and allodynia assessed with PET. Brain 1998;121(Pt 5): 931-947.

Iadarola MJ, Max MB, Berman KF, Byassmith MG, Coghill RC, Gracely RH, et al. Unilateral decrease in thalamic activity observed with positron emission tomography in patients with chronic neuropathic pain. Pain 1995;63:55-64.

Iannetti GD, Truini A, Romaniello A, Galeotti F, Rizzo C, Manfredi $\mathrm{M}$, et al. Evidence of a specific spinal pathway for the sense of warmth in humans. J Neurophysiol 2003;89:562-70.

Inui K, Tran TD, Qiu Y, Wang X, Hoshiyama M, Kakigi R. Painrelated magnetic fields evoked by intra-epidermal electrical stimulation in humans. Clin Neurophysiol 2002;113:298-304.

Jaaskelainen SK, Rinne JO, Forssell H, Tenovuo O, Kaasinen V, Sonninen $\mathrm{P}$, et al. Role of the dopaminergic system in chronic pain - a fluorodopa-PET study. Pain 2001;90:257-60.

Jones AK, Brown WD, Friston KJ, Qi LY, Frackowiak RS. Cortical and subcortical localization of response to pain in man using positron emission tomography. Proc $\mathrm{R}$ Soc Lond $\mathrm{B}$ 1991;244:39-44.

Jones AK, Cunningham VJ, Ha-Kawa S, Fujiwara T, Luthra SK, Silva $S$, et al. Changes in central opioid receptor binding in relation to inflammation and pain in patients with rheumatoid arthritis. Brit J Rheumatol 1994;33:909-16.

Jones AK, Derbyshire SW. Reduced cortical responses to noxious heat in patients with rheumatoid arthritis. Ann Rheum Dis 1997;56:601-7.

Jones AK, Kitchen ND, Watabe H, Cunningham VJ, Jones T, Luthra SK, et al. Measurement of changes in opioid receptor binding in vivo during trigeminal neuralgic pain using $\left[{ }^{11} \mathrm{C}\right]$ diprenorphine and positron emission tomography. J Cereb Blood Flow Metab 1999; 19:803-8.

Jones AP, Hughes DG, Brettle DS, Robinson L, Sykes JR, Aziz Q, et al. Experiences with functional magnetic resonance imaging at 1 tesla. Br J Radiol 1998;71:160-6.

Joseph J, Howland EW, Wakai R, Backonja M, Baffa O, Potenti FM, et al. Late pain-related magnetic fields and electric potentials evoked by intracutaneous electric finger stimulation. Electroencephalogr Clin Neurophysiol 1991;80:46-52. 
Kakigi R, Koyama S, Hoshiyama M, Kitamura Y, Shimojo M, Watanabe S. Pain-related magnetic fields following painful $\mathrm{CO}_{2}$ laser stimulation in man. Neurosci Lett 1995;192:45-8.

Kakigi R, Shibasaki H, Ikeda T, Neshige R, Endo C, Kuroda Y. Painrelated somatosensory evoked potentials following $\mathrm{CO}_{2}$ laser stimulation in peripheral neuropathies. Acta Neurol Scand 1992;85:347-52.

Kakigi R, Tran TD, Qiu Y, Wang X, Nguyen TB, Inui K, et al. Cerebral responses following stimulation of unmyelinated C-fibers in humans: electro- and magneto-encephalographic study. Neurosci Res 2003;45:255-75.

Kanda M, Fujiwara N, Xu X, Shindo K, Nagamine T, Ikeda A, et al. Pain-related and cognitive components of somatosensory evoked potentials following $\mathrm{CO}_{2}$ laser stimulation in man. Electroencephalogr Clin Neurophysiol 1996;100:105-14.

Kanda M, Nagamine T, Ikeda A, Ohara S, Kunieda T, Fujiwara N, et al. Primary somatosensory cortex is actively involved in pain processing in human. Brain Res 2000;853:282-9.

Karl A, Birbaumer N, Lutzenberger W, Cohen LG, Flor H. Reorganization of motor and somatosensory cortex in upper extremity amputees with phantom limb pain. J Neurosci 2001;21:3609-18.

Kenshalo Jr DR, Chudler EH, Anton F, Dubner R. SI nociceptive neurons participate in the encoding process by which monkeys perceive the intensity of noxious thermal stimulation. Brain Res 1988;454:378-82.

Kenshalo Jr DR, Isensee O. Responses of primate SI cortical neurons to noxious stimuli. J Neurophysiol 1983;50:1479-96.

Kitamura Y, Kakigi R, Hoshiyama M, Koyama S, Shimojo M, Watanabe S. Pain-related somatosensory evoked magnetic fields. Electroencephalogr Clin Neurophysiol 1995;95:463-74.

Kitamura Y, Kakigi R, Hoshiyama M, Koyama S, Watanabe S, Shimojo M. Pain-related somatosensory evoked magnetic fields following lower limb stimulation. J Neurol Sci 1997;145:187-94.

Knecht S, Henningsen H, Hohling C, Elbert T, Flor H, Pantev C, et al. Plasticity of plasticity? Changes in the pattern of perceptual correlates of reorganization after amputation. Brain 1998;121 (Pt 4): 717-724.

Korotkov A, Ljubisavljevic M, Thunberg J, Kataeva G, Roudas M, Pakhomov S, et al. Changes in human regional cerebral blood flow following hypertonic saline induced experimental muscle pain: a positron emission tomography study. Neurosci Lett 2002;335:119-23.

Kunde V, Treede RD. Topography of middle-latency somatosensory evoked potentials following painful laser stimuli and non-painful electrical stimuli. Electroencephalogr Clin Neurophysiol 1993;88:280-9.

Kurata J, Thulborn KR, Gyulai FE, Firestone LL. Early decay of pain-related cerebral activation in functional magnetic resonance imaging: comparison with visual and motor tasks. Anesthesiology 2002;96:35-44.

Kwan CL, Crawley AP, Mikulis DJ, Davis KD. An fMRI study of the anterior cingulate cortex and surrounding medial wall activations evoked by noxious cutaneous heat and cold stimuli. Pain 2000;85:359-74.

Ladabaum U, Minoshima S, Hasler WL, Cross D, Chey WD, Owyang C. Gastric distention correlates with activation of multiple cortical and subcortical regions. Gastroenterology 2001;120:369-76.

Lassen NA, Ingvar DH, Skinhoj E. Brain function and blood flow. Sci Am 1978;239:62-71.

Legrain V, Guerit JM, Bruyer R, Plaghki L. Attentional modulation of the nociceptive processing into the human brain: selective spatial attention, probability of stimulus occurrence, and target detection effects on laser evoked potentials. Pain 2002;99:21-39.

Lenz FA, Rios M, Chau D, Krauss GL, Zirh TA, Lesser RP. Painful stimuli evoke potentials recorded from the parasylvian cortex in humans. J Neurophysiol 1998;80:2077-88.
Lenz FA, Rios M, Zirh A, Chau D, Krauss G, Lesser RP. Painful stimuli evoke potentials recorded over the human anterior cingulate gyrus. J Neurophysiol 1998;79:2231-4.

Longe SE, Wise R, Bantick S, Lloyd D, Johansen-Berg H, McGlone F, et al. Counter-stimulatory effects on pain perception and processing are significantly altered by attention: an fMRI study. Neuroreport 2001;12:2021-5.

Loose R, Schnitzler A, Sarkar S, Schmitz F, Volkmann J, Frieling T, et al. Cortical activation during oesophageal stimulation: a neuromagnetic study. Neurogastroenterol Motil 1999;11:163-71.

Lorenz J, Beck H, Bromm B. Differential changes of laser evoked potentials, late auditory evoked potentials and P300 under morphine in chronic pain patients. Electroencephalogr Clin Neurophysiol 1997;104:514-21.

Lorenz J, Bromm B. Event-related potential correlates of interference between cognitive performance and tonic experimental pain. Psychophysiology 1997;34:436-45.

Lorenz J, Cross DJ, Minoshima S, Morrow TJ, Paulson PE, Casey $\mathrm{KL}$. A unique representation of heat allodynia in the human brain. Neuron 2002;35:383-93.

Lorenz J, Grasedyck K, Bromm B. Middle and long latency somatosensory evoked potentials after painful laser stimulation in patients with fibromyalgia syndrome. Electroencephalogr Clin Neurophysiol 1996;100:165-8.

Maeda K, Kakigi R, Hoshiyama M, Koyama S. Topography of the secondary somatosensory cortex in humans: a magnetoencephalographic study. Neuroreport 1999;10:301-6.

Magerl W, Ali Z, Ellrich J, Meyer RA, Treede RD. C- and A deltafiber components of heat-evoked cerebral potentials in healthy human subjects. Pain 1999;82:127-37.

Maihofner C, Kaltenhauser M, Neundorfer B, Lang E. Temporospatial analysis of cortical activation by phasic innocuous and noxious cold stimuli - a magnetoencephalographic study. Pain 2002;100:281-90.

May A, Bahra A, Buchel C, Frackowiak RSJ, Goadsby PJ. Hypothalamic activation in cluster headache attacks. Lancet 1998;352:275-8.

May A, Bahra A, Buchel C, Frackowiak RS, Goadsby PJ. PET and MRA findings in cluster headache and MRA in experimental pain. Neurology 2000;55:1328-35.

Meier W, Klucken M, Soyka D, Bromm B. Hypnotic hypo- and hyperalgesia: divergent effects on pain ratings and pain-related cerebral potentials. Pain 1993;53:175-81.

Mertz H, Morgan V, Tanner G, Pickens D, Price R, Shyr Y, et al. Regional cerebral activation in irritable bowel syndrome and control subjects with painful and nonpainful rectal distention. Gastroenterology 2000;118:842-8.

Mesulam MM, Mufson EJ. Insula of the old world monkey. I. Architectonics in the insulo-orbito-temporal component of the paralimbic brain. J Comp Neurol 1982;212:1-22.

Miyazaki M, Shibasaki H, Kanda M, Xu X, Shindo K, Honda M, et al. Generator mechanism of pain-related evoked potentials following $\mathrm{CO}_{2}$ laser stimulation of the hand: scalp topography and effect of predictive warning signal. J Clin Neurophysiol 1994;11:242-54.

Montoya P, Ritter K, Huse E, Larbig W, Braun C, Topfner S, et al. The cortical somatotopic map and phantom phenomena in subjects with congenital limb atrophy and traumatic amputees with phantom limb pain. Eur J Neurosci 1998;10: $1095-102$.

Nakai A, Kumakura Y, Boivin M, Rosa P, Diksic M, D’Souza D, et al. Sex differences of brain serotonin synthesis in patients with irritable bowel syndrome using a $\left[{ }^{11} \mathrm{C}\right]$ methyl-1-tryptophan, positron emission tomography and statistical parametric mapping. Can J Gastroenterol 2003;17:191-6.

Nakamura Y, Paur R, Zimmermann R, Bromm B. Attentional modulation of human pain processing in the secondary somato- 
sensory cortex: a magnetoencephalographic study. Neurosci Lett 2002;328:29-32.

Naliboff BD, Derbyshire SW, Munakata J, Berman S, Mandelkern M, Chang L, et al. Cerebral activation in patients with irritable bowel syndrome and control subjects during rectosigmoid stimulation. Psychosom Med 2001;63:365-75.

Niddam DM, Yeh TC, Wu YT, Lee PL, Ho LT, Arendt-Nielsen L, et al. Event-related functional MRI study on central representation of acute muscle pain induced by electrical stimulation. Neuroimage 2002;17:1437-50.

Ninomiya Y, Kitamura Y, Yamamoto S, Okamoto M, Oka H, Yamada N, et al. Analysis of pain-related somatosensory evoked magnetic fields using the MUSIC (multiple signal classification) algorithm for magnetoencephalography. Neuroreport 2001;12:1657-61.

Opsommer E, Weiss T, Plaghki L, Miltner WH. Dipole analysis of ultralate (C-fibres) evoked potentials after laser stimulation of tiny cutaneous surface areas in humans. Neurosci Lett 2001;298:41-4.

Oshiro Y, Fuijita N, Tanaka H, Hirabuki N, Nakamura H, Yoshiya I. Functional mapping of pain-related activation with echo-planar MRI: significance of the SII-insular region. Neuroreport 1998;9:2285-9.

Pattany PM, Yezierski RP, Widerstrom-Noga EG, Bowen BC, Martinez-Arizala A, Garcia BR, et al. Proton magnetic resonance spectroscopy of the thalamus in patients with chronic neuropathic pain after spinal cord injury. AJNR Am J Neuroradiol 2002;23:901-5.

Paulson PE, Minoshima S, Morrow TJ, Casey KL. Gender differences in pain perception and patterns of cerebral activation during noxious heat stimulation in humans. Pain 1998;76:223-9.

Petrovic P, Ingvar M, Stone-Elander S, Petersson KM, Hansson P. A PET activation study of dynamic mechanical allodynia in patients with mononeuropathy. Pain 1999;83:459-70.

Petrovic P, Kalso E, Petersson KM, Ingvar M. Placebo and opioid analgesia - imaging a shared neuronal network. Science 2002;295:1737-40.

Petrovic P, Petersson KM, Ghatan PH, Stone-Elander S, Ingvar M. Pain-related cerebral activation is altered by a distracting cognitive task. Pain 2000;85:19-30.

Petrovic P, Petersson KM, Hansson P, Ingvar M. A regression analysis study of the primary somatosensory cortex during pain. Neuroimage 2002;16:1142-50.

Peyron R, Frot M, Schneider F, Garcia-Larrea L, Mertens P, Barral FG, et al. Role of operculoinsular cortices in human pain processing: converging evidence from PET, fMRI, dipole modeling, and intracerebral recordings of evoked potentials. Neuroimage 2002;17:1336-46.

Peyron R, Garcia-Larrea L, Gregoire MC, Costes N, Convers P, Lavenne $\mathrm{F}$, et al. Haemodynamic brain responses to acute pain in humans: sensory and attentional networks. Brain 1999;122(Pt ):1765-80.

Peyron R, Laurent B, Garcia-Larrea L. Functional imaging of brain responses to pain. A review and meta-analysis (2000). Neurophysiol Clin 2000;30:263-88.

Phillips ML, Gregory LJ, Cullen S, Cohen S, Ng V, Andrew C, et al. The effect of negative emotional context on neural and behavioural responses to oesophageal stimulation. Brain 2003;126:669-84.

Plaghki L, Delisle D, Godfraind JM. Heterotopic nociceptive conditioning stimuli and mental task modulate differently the perception and physiological correlates of short $\mathrm{CO}_{2}$ laser stimuli. Pain 1994;57:181-92.

Ploghaus A, Narain C, Beckmann CF, Clare S, Bantick S, Wise R, et al. Exacerbation of pain by anxiety is associated with activity in a hippocampal network. J Neurosci 2001;21:9896-903.

Ploghaus A, Tracey I, Clare S, Gati JS, Rawlins JN, Matthews PM. Learning about pain: the neural substrate of the prediction error for aversive events. Proc Natl Acad Sci USA 2000;97:9281-6.
Ploghaus A, Tracey I, Gati JS, Clare S, Menon RS, Matthews PM, et al. Dissociating pain from its anticipation in the human brain. Science 1999;284:1979-81.

Ploner M, Gross J, Timmermann L, Schnitzler A. Cortical representation of first and second pain sensation in humans. Proc Natl Acad Sci USA 2002;99:12444-8.

Ploner M, Gross J, Timmermann L, Schnitzler A. Cortical representation of first and second pain sensation in humans. Proc Natl Acad Sci USA 2002;99:12444-8.

Ploner M, Schmitz F, Freund HJ, Schnitzler A. Parallel activation of primary and secondary somatosensory cortices in human pain processing. J Neurophysiol 1999;81:3100-4.

Ploner M, Schmitz F, Freund HJ, Schnitzler A. Differential organization of touch and pain in human primary somatosensory cortex. J Neurophysiol 2000;83:1770-6.

Porro CA, Baraldi P, Pagnoni G, Serafini M, Facchin P, Maieron M, et al. Does anticipation of pain affect cortical nociceptive systems? J Neurosci 2002;22:3206-14.

Porro CA, Cettolo V, Francescato MP, Baraldi P. Temporal and intensity coding of pain in human cortex. J Neurophysiol 1998;80:3312-20.

Price DD. Psychological and neural mechanisms of the affective dimension of pain. Science 2000;288:1769-72.

Pridmore S, Oberoi G. Transcranial magnetic stimulation applications and potential use in chronic pain: studies in waiting. J Neurol Sci 2000;182:1-4.

Rainville P, Duncan GH, Price DD, Carrier B, Bushnell MC. Pain affect encoded in human anterior cingulate but not somatosensory cortex. Science 1997;277:968-71.

Reinert A, Treede R, Bromm B. The pain inhibiting pain effect: an electrophysiological study in humans. Brain Res 2000;862:103-10.

Rolls ET, O'Doherty J, Kringelbach ML, Francis S, Bowtell R, McGlone F. Representations of pleasant and painful touch in the human orbitofrontal and cingulate cortices. Cereb Cortex 2003;13:308-17.

Rosen SD, Paulesu E, Frith CD, Frackowiak RS, Davies GJ, Jones T, et al. Central nervous pathways mediating angina pectoris. Lancet 1994:344:147-50.

Rosen SD, Paulesu E, Nihoyannopoulos P, Tousoulis D, Frackowiak RS, Frith CD, et al. Silent ischemia as a central problem: regional brain activation compared in silent and painful myocardial ischemia. Ann Intern Med 1996;124:939-49.

Rosen SD, Paulesu E, Wise RJ, Camici PG. Central neural contribution to the perception of chest pain in cardiac syndrome X. Heart 2002;87:513-9.

Sanchez dR, Bakker D, Wu O, Agosti R, Mitsikostas DD, Ostergaard $\mathrm{L}$, et al. Perfusion weighted imaging during migraine: spontaneous visual aura and headache. Cephalalgia 1999;19:701-7.

Sawamoto N, Honda M, Okada T, Hanakawa T, Kanda M, Fukuyama H, et al. Expectation of pain enhances responses to nonpainful somatosensory stimulation in the anterior cingulate cortex and parietal operculum/posterior insula: an event-related functional magnetic resonance imaging study. J Neurosci 2000;20:7438-45.

Schlaepfer TE, Strain EC, Greenberg BD, Preston KL, Lancaster E, Bigelow GE, et al. Site of opioid action in the human brain: mu and kappa agonists' subjective and cerebral blood flow effects. Am J Psychiatry 1998;155:470-3.

Siedenberg R, Treede RD. Laser-evoked potentials: exogenous and endogenous components. Electroencephalogr Clin Neurophysiol 1996;100:240-9.

Silverman DH, Munakata JA, Ennes H, Mandelkern MA, Hoh CK, Mayer EA. Regional cerebral activity in normal and pathological perception of visceral pain. Gastroenterology 1997;112:64-72.

Smith YR, Zubieta JK, del Carmen MG, Dannals RF, Ravert HT, Zacur HA, et al. Brain opioid receptor measurements by positron emission tomography in normal cycling women: relationship to 
luteinizing hormone pulsatility and gonadal steroid hormones. J Clin Endocrinol Metab 1998;83:4498-505.

Spiegel J, Hansen C, Treede RD. Clinical evaluation criteria for the assessment of impaired pain sensitivity by thulium-laser evoked potentials. Clin Neurophysiol 2000;111:725-35.

Spreng M, Ichioka M. Langsame Rindenpotentiale bei Schmerzreizung am Menschen. Pflugers Arch 1964;279:121-32.

Strigo IA, Duncan GH, Boivin M, Bushnell MC. Differentiation of visceral and cutaneous pain in the human brain. J Neurophysiol 2003;89:3294-303.

Svensson P, Johannsen P, Jensen TS, Arendt-Nielsen L, Nielsen J, Stodkilde-Jorgensen $\mathrm{H}$, et al. Cerebral blood-flow changes evoked by two levels of painful heat stimulation: a positron emission tomography study in humans. Eur J Pain 1998;2:95-107.

Svensson P, Minoshima S, Beydoun A, Morrow TJ, Casey KL. Cerebral processing of acute skin and muscle pain in humans. J Neurophysiol 1997;78:450-60.

Talbot JD, Marrett S, Evans AC, Meyer E, Bushnell MC, Duncan GH. Multiple representations of pain in human cerebral cortex. Science 1991;251:1355-8.

Tarkka IM, Treede RD. Equivalent electrical source analysis of painrelated somatosensory evoked potentials elicited by a $\mathrm{CO}_{2}$ laser. $\mathrm{J}$ Clin Neurophysiol 1993;10:513-9.

Timmermann L, Ploner M, Haucke K, Schmitz F, Baltissen R, Schnitzler A. Differential coding of pain intensity in the human primary and secondary somatosensory cortex. J Neurophysiol 2001;86:1499-503.

Tolle TR, Kaufmann T, Siessmeier T, Lautenbacher S, Berthele A, Munz F, et al. Region-specific encoding of sensory and affective components of pain in the human brain: a positron emission tomography correlation analysis. Ann Neurol 1999;45:40-7.

Torquati K, Pizzella V, Della PS, Franciotti R, Babiloni C, Rossini $\mathrm{PM}$, et al. Comparison between SI and SII responses as a function of stimulus intensity. Neuroreport 2002;13:813-9.

Tracey I, Becerra L, Chang I, Breiter H, Jenkins L, Borsook D, et al. Noxious hot and cold stimulation produce common patterns of brain activation in humans: a functional magnetic resonance imaging study. Neurosci Lett 2000;288:159-62.

Tracey I, Ploghaus A, Gati JS, Clare S, Smith S, Menon RS, et al. Imaging attentional modulation of pain in the periaqueductal gray in humans. J Neurosci 2002;22:2748-52.

Tran TD, Inui K, Hoshiyama M, Lam K, Qiu Y, Kakigi R. Cerebral activation by the signals ascending through unmyelinated C-fibers in humans: a magnetoencephalographic study. Neuroscience 2002;113:375-86.

Treede RD, Kief S, Holzer T, Bromm B. Late somatosensory evoked cerebral potentials in response to cutaneous heat stimuli. Electroencephalogr Clin Neurophysiol 1988;70:429-41.

Treede RD, Lankers J, Frieling A, Zangemeister WH, Kunze K, Bromm B. Cerebral potentials evoked by painful, laser stimuli in patients with syringomyelia. Brain 1991;114(Pt 4):1595-607.

Truini A, Haanpaa M, Zucchi R, Galeotti F, Iannetti GD, Romaniello A, et al. Laser-evoked potentials in post-herpetic neuralgia. Clin Neurophysiol 2003;114:702-9.

Valeriani M, Rambaud L, Mauguiere F. Scalp topography and dipolar source modelling of potentials evoked by $\mathrm{CO}_{2}$ laser stimulation of the hand. Electroencephalogr Clin Neurophysiol 2003;100:343-53.

Valeriani M, Le Pera D, Niddam D, Arendt-Nielsen L, Chen AC. Dipolar source modeling of somatosensory evoked potentials to painful and nonpainful median nerve stimulation. Muscle Nerve 2000;23:1194-203.
Valeriani M, Restuccia D, DiLazzaro V, Franceschi F, Fabbriciani C, Tonali P. Central nervous system modifications in patients with lesion of the anterior cruciate ligament of the knee. Brain 1996;119(Pt 5):1751-62.

Valeriani M, Restuccia D, Le Pera D, De Armas L, Maiese T, Tonali P. Attention-related modifications of ultra-late $\mathrm{CO}(2)$ laser evoked potentials to human trigeminal nerve stimulation. Neurosci Lett 2002;329:329-33.

Villemure C, Bushnell MC. Cognitive modulation of pain: how do attention and emotion influence pain processing? Pain 2002;95:195-9.

Vogel H, Port JD, Lenz FA, Solaiyappan M, Krauss G, Treede RD. Dipole source analysis of laser-evoked subdural potentials recorded from parasylvian cortex in humans. J Neurophysiol 2003;89:3051-60.

Vogt BA, Derbyshire S, Jones AK. Pain processing in four regions of human cingulate cortex localized with co-registered PET and MR imaging. Eur J Neurosci 1996;8:1461-73.

Wagner KJ, Willoch F, Kochs EF, Siessmeier T, Tolle TR, Schwaiger $\mathrm{M}$, et al. Dose-dependent regional cerebral blood flow changes during remifentanil infusion in humans: a positron emission tomography study. Anesthesiology 2001;94:732-9.

Watanabe S, Kakigi R, Koyama S, Hoshiyama M, Kaneoke Y. Pain processing traced by magnetoencephalography in the human brain. Brain Topogr 1998;10:255-64.

Weiller C, May A, Limmroth V, Juptner M, Kaube H, Schayck RV, et al. Brain stem activation in spontaneous human migraine attacks. Nat Med 1995;1:658-60.

Wiech K, Preissl H, Birbaumer N. Neuroimaging of chronic pain: phantom limb and musculoskeletal pain. Scand J Rheumatol Suppl 2000;113:13-8.

Wik G, Fischer H, Bragee B, Finer B, Fredrikson M. Functional anatomy of hypnotic analgesia: a PET study of patients with fibromyalgia. Eur J Pain 1999;3:7-12.

Willoch F, Rosen G, Tolle TR, Oye I, Wester HJ, Berner N, et al. Phantom limb pain in the human brain: unraveling neural circuitries of phantom limb sensations using positron emission tomography. Ann Neurol 2000;48:842-9.

Witting N, Kupers RC, Svensson P, Arendt-Nielsen L, Gjedde A, Jensen TS. Experimental brush-evoked allodynia activates posterior parietal cortex. Neurology 2001;57:1817-24.

Xu X, Fukuyama H, Yazawa S, Mima T, Hanakawa T, Magata Y, et al. Functional localization of pain perception in the human brain studied by PET. Neuroreport 1997;8:555-9.

Yamasaki H, Kakigi R, Watanabe S, Naka D. Effects of distraction on pain perception: magneto- and electro-encephalographic studies. Brain Res Cogn Brain Res 1999;8:73-6.

Zacny JP. Morphine responses in humans: a retrospective analysis of sex differences. Drug Alcohol Depend 2001;63:23-8.

Zubieta JK, Dannals RF, Frost JJ. Gender and age influences on human brain mu-opioid receptor binding measured by PET. Am J Psychiatry 1999;156:842-8.

Zubieta JK, Heitzeg MM, Smith YR, Bueller JA, Xu K, Xu Y, et al. COMT val158met genotype affects mu-opioid neurotransmitter responses to a pain stressor. Science 2003;299:1240-3.

Zubieta JK, Smith YR, Bueller JA, Xu Y, Kilbourn MR, Jewett DM, et al. Regional $\mu$ opioid receptor regulation of sensory and affective dimensions of pain. Science 2001;293:311-5.

Zubieta JK, Smith YR, Bueller JA, Xu Y, Kilbourn MR, Jewett DM, et al. $\mu$-Opioid receptor-mediated antinociceptive responses differ in men and women. J Neurosci 2002;22:5100-7. 